\title{
Phidianidine A and Synthetic Analogues as Naturally Inspired Marine Antifoulants
}

\author{
Christophe Labriere, Vijayaragavan Elumalai, Jannie Staffansson, Gunnar Cervin, Tiffany Le Norcy, \\ Hugo Denardou, Karine Réhel, Lindon W. K. Moodie, Claire Hellio, Henrik Pavia, Jørn H. Hansen, \\ and Johan Svenson*
}

Cite This: J. Nat. Prod. 2020, 83, 3413-3423

Read Online

ACCESS | 네 Metrics \& More | 回 Article Recommendations | sl Supporting Information

ABSTRACT: Stationary and slow-moving marine organisms regularly employ a natural product chemical defense to prevent being colonized by marine micro- and macroorganisms. While these natural antifoulants can be structurally diverse, they often display highly conserved chemistries and physicochemical properties, suggesting a natural marine antifouling pharmacophore. In our current report, we investigate the marine natural product phidianidine $\mathrm{A}$, which displays several chemical properties found in highly potent marine antifoulants. Phidianidine $\mathrm{A}$ and synthetic analogues were screened against the settlement and metamorphosis of Amphibalanus improvisus cyprids, and several of the compounds displayed inhibitory activities at low micromolar concentrations with $\mathrm{IC}_{50}$ values down to $0.7 \mu \mathrm{g} / \mathrm{mL}$ observed. The settlement study highlights that phidianidine $\mathrm{A}$ is a potent natural antifoulant and that the scaffold can be

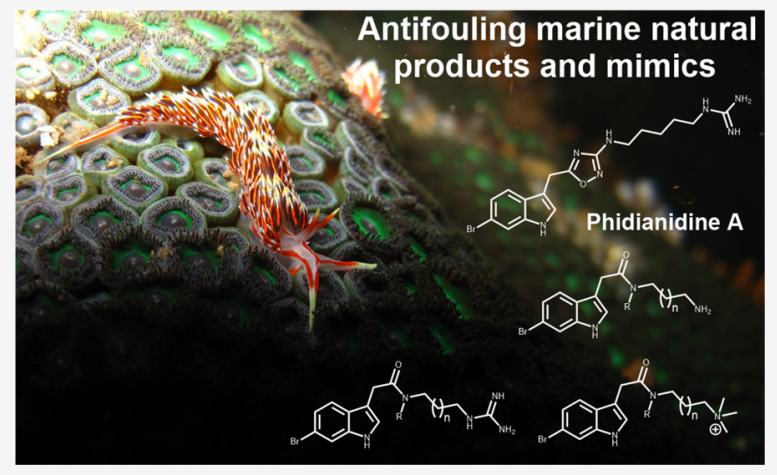
tuned to generate simpler and improved synthetic analogues. The bioactivity is closely linked to the size of the compound and to its basicity. The study also illustrates that active analogues can be prepared in the absence of the natural constrained 1,2,4-oxadiazole ring. A synthetic lead analogue of phidianidine A was incorporated in a coating and included in antifouling field trials, where it was shown that the coating induced potent inhibition of marine bacteria and microalgae settlement.

$\mathrm{M}$ arine organisms represent a rich source of novel bioactive natural products with significant chemical diversity and high potency. ${ }^{1,2}$ As a result, several drugs and drug leads in clinical trials are of marine origin. ${ }^{3,4}$ While slowmoving marine organisms are under a constant threat from predators, sessile organisms also have to deal with the dangers of being colonized and overgrown. In response to these threats, several marine organisms have developed a sophisticated chemical defense to deter predators, colonizers, and competitors. ${ }^{1,5}$ Several of these natural products do not directly kill their target organisms but instead function as repellants at low concentrations toward colonizing marine micro- and macroorganisms by acting as antifoulants. ${ }^{6,7}$

Being able to prevent the settlement and fouling of marine structures by marine organisms is complicated, and biofouling countermeasures represent a significant challenge and cost for many marine industries. ${ }^{8,9}$ Biofouling is a rapid and naturally occurring process affecting all untreated submerged surfaces which results in unwanted maintenance costs. ${ }^{8,10}$ The main challenges are associated with the loss of structural integrity and performance (often increased drag) by the added weight and thickness/rugosity to marine devices and structure. ${ }^{11}$ Furthermore, biofouling may promote corrosion, which significantly reduces the effective operation life-span of marine equipment. $^{12}$ Methods to provide effective and long-term marine surface protection without general toxicity to nontarget marine organisms are lacking. ${ }^{13}$ Hence there is an unmet need for novel and environmentally friendly antifouling solutions. Developing repelling antifouling compounds inspired by Nature represent a promising strategy. 6,13

A particular group of marine natural products (MNP) with broad antifouling activities are brominated dipeptidic derivatives often isolated from stationary marine organisms. ${ }^{5}$ The MNPs in this group share several structural features such as a brominated aromatic moiety, regularly tyrosine or tryptophan, a constrained or heterocyclic center, and often a cationic arm terminated with a guanidine derivative. Ianthelline, initially discovered in the Bahamian sponge Ianthella $\operatorname{ardis}^{14}$ has recently been shown to be a potent natural antifoulant. ${ }^{15}$ Ianthelline inhibits the settlement and metamorphosis of barnacle cyprids $\left(\mathrm{IC}_{50}=6 \mu \mathrm{M}\right)$ and also displays a pronounced

Received: August 7, 2020

Published: October 15, 2020 

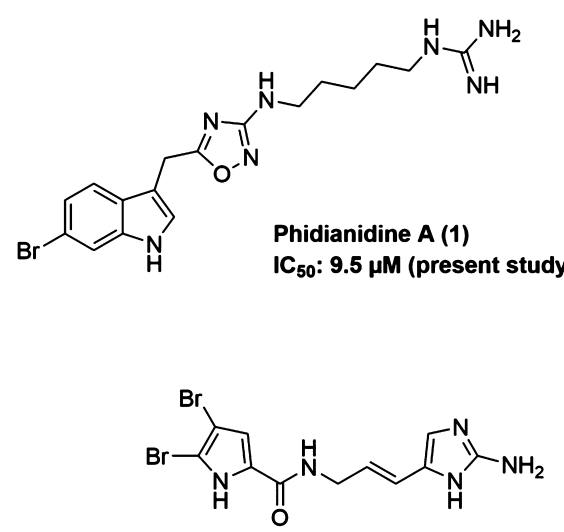

Oroidin IC $_{50}: 49 \mu \mathrm{M}$<smiles>COc1c(Br)cc(CC(=O)NCCc2c[nH]c(=N)[nH]2)c(Br)c1Br</smiles>

lanthelline $\mathrm{IC}_{50}: 6 \mu \mathrm{M}$<smiles>COc1c(Br)cc(/C=C2\OC(C(Cl)CCNC(=N)N)NC2=O)cc1Br</smiles>

Synoxazolidinone A $I_{50}: 15 \mu \mathrm{M}$<smiles>N=C(N)NCCC[C@H]1NC(=O)/C(=C/c2c[nH]c3cc(Br)ccc23)NC1=O</smiles>

Barettin ${ }^{\prime C} \mathrm{C}_{50}: 0.9 \mu \mathrm{M}$<smiles>O=C(NCCc1cc(Br)c(O)c(Br)c1)/C(Cc1cc(Br)c(O)c(Br)c1)=N/O</smiles>

${ }^{\prime C_{50}}$ : $10 \mu \mathrm{M}$

Figure 1. Chemical structure of phidianidine A (1) and a selection of natural potent marine barnacle settlement inhibitors with inhibitory concentration $\left(\mathrm{IC}_{50}\right)$ included.

effect on marine bacteria (minimum inhibitory concentration (MIC) values $0.1-10 \mu \mathrm{g} / \mathrm{mL}){ }^{15}$ The 2,5-diketopiperazine barettin, initially isolated from the sponge Geodia baretti in Swedish waters together with structural analogues, prevents the settlement of Amphibalanus improvisus at $0.9 \mu \mathrm{M}$ concentrations. ${ }^{16}$ The high potency of barettin has spurred the synthesis of simplified analogues with ranging bioactivities. $^{17-19}$ The pyrrole-imidazole oroidin is found in sponges of the Agelasidae family where it is considered a likely biogenic precursor to bromoageliferin $1 .^{20}$ In addition to being able to inhibit marine bacterial colonization and biofilm formation, ${ }^{21}$ oroidin has also been shown in analogy to both ianthelline and barettin, to be a moderate inhibitor of barnacle settlement with a reported $\mathrm{IC}_{50}$ value of $49 \mu \mathrm{M} .^{22}$ Furthermore, the synoxazolidinones from the cold-water colonial ascidian Synoicum pulmonaria ${ }^{23-25}$ and the numerous bastadin analogues commonly isolated from Ianthella marine sponges have also been assigned as potent inhibitors of marine microand macrofouling. ${ }^{5,26,27}$ A selection of potent natural marine inhibitors of barnacle settlement are presented in Figure 1.

Several of the reported marine antifoulants have also been reported with other bioactivities such as antitumoral, antiinflammatory, ${ }^{18,28}$ antibacterial, $^{21,23}$ and as inhibitors of acetylcholinesterase. ${ }^{29,30}$

Phidianidine A (1), with an uncommon 1,2,4-oxadiazole ring linked to the brominated indole system, is a MNP isolated from the aeolid opisthobranch mollusk Phidiana militaris. ${ }^{31}$ Compound $\mathbf{1}$ is structurally and chemically highly analogous to ianthelline, barettin, and the synoxazolidinones and thus displays the structural features often linked to a high antifouling activity. Initial studies of 1 revealed cytotoxic ${ }^{31}$ activity, and more recently, $\mathbf{1}$ and synthetic analogues showed immunosuppressive properties. ${ }^{32}$ In addition, 1 was also shown to be a selective inhibitor of the dopamine transporter and a selective, potent ligand and partial agonist of the $\mu$-opioid receptor (versus $\delta$ - and $\kappa$-opioid receptors). ${ }^{33}$ Furthermore, 1 was identified using virtual screening and experimentally verified as a new antagonist of CXCR4 which is a chemokine receptor associated with several diseases like HIV, rheumatoid arthritis, and cancer. ${ }^{34}$

Inspired by the structural resemblance of 1 with several reported highly active antifouling MNPs and the straightforward synthetic tools available for modification, the current study is aimed at evaluation of the antifouling properties of 1 and synthetic analogues. In this report, 1 and a library of 10 synthesized analogues $(\mathbf{8} \mathbf{a}-\mathbf{e}, \mathbf{9 a}-\mathbf{d}, \mathbf{1 0})$ were prepared and evaluated for the ability to prevent the settlement of $A$. improvisus cyprid. Furthermore, the most promising compound was formulated into a coating and evaluated in field studies for 3 months.

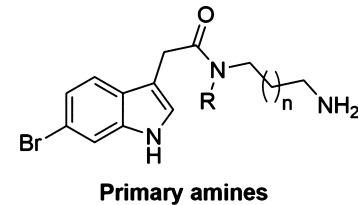

8a: $R=H, n=1,8 b: R=H, n=2$ 8c: $R=H, n=3,8 d: R=H, n=4$ 8e: $\mathrm{R}=\mathrm{CH}_{3}, \mathrm{n}=4$<smiles>[R]N(CCCN(C)C)C(=O)Cc1c[nH]c2cc(Br)ccc12</smiles>

\section{RESULTS AND DISCUSSION}

Library Design and Synthesis. The library of compounds was designed to probe the contribution of structure to the activity as previously successfully demonstrated for natural antifoulants. ${ }^{35-37}$ With an emphasis on ease of preparation, only 1 was prepared with the 1,2,4-oxadiazole ring motif according to published routes. ${ }^{38}$ The rest of the analogues were designed with an amide bond linkage between the brominated indole and the cationic arm. Studies by Lin and Snider have reported a significant loss of activity when the indole bromine is excluded in analogues of $\mathbf{1}$ and it was decided to keep the 6-bromoindole motif intact. ${ }^{38}$ These observations have also been reported for analogues of barettin and the synoxazolidinones when the halogens are removed. ${ }^{5}$ Instead focus was placed on the length of the cationic arm and the nature of the terminal cationic group, amine vs guanidine. Two of the compounds were also $N$-methylated and one also contained a quaternary ammonium group. Compound $\mathbf{1}$ and its analogues 8-10 were all prepared in generally good yields 


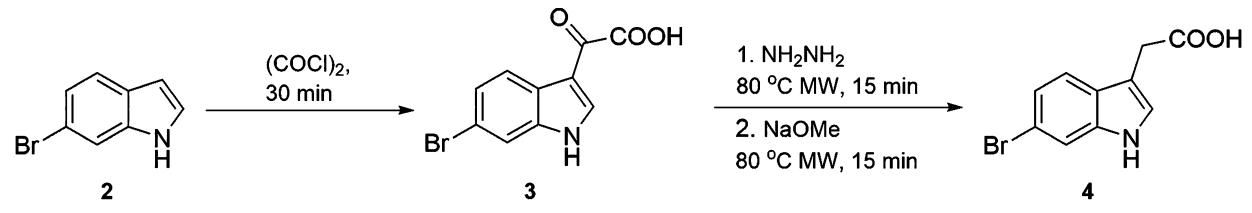

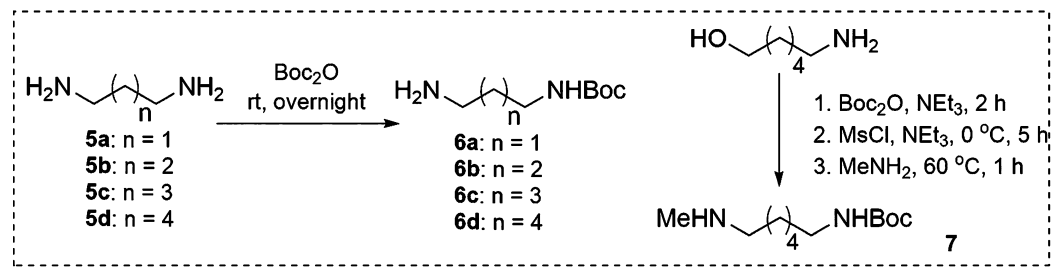<smiles>[R]N(CC=CCNC(=N)N)C(=O)Cc1c[nH]c2cc(Br)ccc12</smiles>

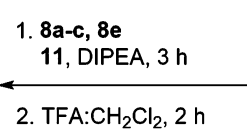<smiles>[R]N(CN=CCN)C(=O)Cc1c[nH]c2cc(Br)ccc12</smiles>

$9 a: R=H, n=1,9 b: R=H, n=2$ 9c: $R=H, n=3,9 d: R=\mathrm{CH}_{3}, \mathrm{n}=4$<smiles>[R]N(CCN(C)C)C(=O)Cc1c[nH]c2cc(Br)ccc12</smiles>

10: $R=H, n=1$

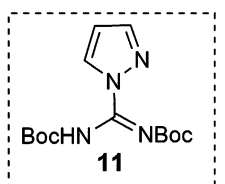

8c: $R=H, n=3,8 d: R=H, n=4$

8e: $\mathrm{R}=\mathrm{CH}_{3}, \mathrm{n}=4$ 8a: $R=H, n=1,8 b: R=H, n=2$

Figure 2. Synthetic outline for compounds 8-10.

with the exception of the $N$-methylated $8 \mathbf{e}$ and $9 d$ ( 8 and $26 \%$, respectively). The synthetic scheme employed for preparing compounds 8-10 is outlined in Figure 2.

Barnacle Settlement. Several MNPs displaying the functionalities of $\mathbf{1}$ and analogues have been linked to significant inhibitory potency against the settlement and subsequent metamorphosis of barnacle cyprids. To evaluate the potential of the prepared library as settlement inhibitors, they were tested against $A$. improvisus cyprid larvae. Barnacles represent a major fouling organism, ${ }^{10}$ and their tiny footprint and colonization of man-made surfaces results in huge economical implications, leading to multibillion dollar maintenance costs. ${ }^{39,40} \mathrm{~A}$. improvisus originates from the east coast of the American continent but is today spread worldwide via shipping. ${ }^{41}$ It represents a major fouling organism and is commonly found on rocks, jetties, and boat hulls where it forms dense colonies on suitable substrata. ${ }^{39}$ The extreme tolerance to ranging salinity makes A. improvisus a relevant model for studies on both biofouling and osmoregulation. ${ }^{41}$

Most of the evaluated compounds displayed inhibitory effects on the settlement of the barnacle cyprids, and the dose response behavior allowed evaluation of the $\mathrm{IC}_{50}$ values for compounds displaying $<50 \%$ settlement at $5 \mu \mathrm{g} / \mathrm{mL}$. The degree of inhibition of the compounds and also their potential cyprid toxicity is compiled and compared to the positive control Sea-nine and potent MNPs in Table 1.

Compound 1 displayed an $\mathrm{IC}_{50}$ of $4.0 \mu \mathrm{g} / \mathrm{mL}$ and thus it compares well with other established MNPs such as ianthelline, ${ }^{15}$ barretin $^{16}$ and synoxazolidione A. ${ }^{5}$ A 3\% mortality of the cyprids was observed at $5 \mu \mathrm{g} / \mathrm{mL}$ which is similar to the negative DMSO control (2.4\%) and illustrates that 1 exerts its inhibitory activity via a nontoxic mechanism at the employed
Table 1. Potency and Toxicity of Tested Compounds against the Barnacle $A$. improvisus

$\begin{array}{cccc}\text { compound } & \text { metamorphosis }(\%) & \mathrm{IC}_{50}(\mu \mathrm{g} / \mathrm{mL}) & \text { toxicity }(\%)^{a} \\ \text { phidianidine A (1) } & 9 & 4.0 & 3 \\ \text { 8a } & 66 & >5.0 & 4 \\ \text { 8b } & 77 & >5.0 & 0 \\ \text { 8c } & 58 & >5.0 & 3 \\ \text { 8d } & 72 & >5.0 & 0 \\ \text { 8e } & 58 & >5.0 & 4 \\ \text { 9a } & 67 & >5.0 & 0 \\ 9 \mathbf{b} & 73 & >5.0 & 0 \\ \text { 9c } & 27 & 2.2 & 0 \\ \text { 9d } & 5 & 0.7 & 6 \\ \text { 10 } & 74 & >5.0 & 2 \\ \text { sea-nine }^{b} & \text { n.d. } & 0.25 & \text { n. } \mathrm{d}^{c} \\ \text { ianthelline }^{d} & 10 & 3.0 & 14 \\ \text { barretin }^{e} & \text { n.d. } & 1.0 & \text { n.d. } \\ \text { synoxazolidinone }^{f} & 54 & 7.4 & 2\end{array}$

${ }^{a}$ Reported at $5 \mu \mathrm{g} / \mathrm{mL}$. Toxicity for the negative control DMSO $(0.1 \%, \mathrm{v} / \mathrm{v})$ in filtered seawater was $2.4 \% .{ }^{b}$ Data from Moodie et al. ${ }^{36}$ ${ }^{c}$ Not determined. ${ }^{d}$ Data from Hanssen et al. ${ }^{15}{ }^{e}$ Data from Sjögren et al. ${ }^{16} f_{\text {Data }}$ from Trepos et al. ${ }^{5}$

concentrations. While several of the simplified synthetic compounds were inactive at $5 \mu \mathrm{g} / \mathrm{mL}$, compounds $9 \mathrm{c}$ and 9d displayed potent inhibitory properties with $\mathrm{IC}_{50}$ values lower than those observed for 1 at 2.2 and $0.7 \mu \mathrm{g} / \mathrm{mL}$ respectively. Compound 9d was the most effective inhibitor with activity superior to several potent antifouling MNPs. ${ }^{6}$ In addition, the toxicity of $\mathbf{9 d}$ was low as illustrated in Figure 3. 


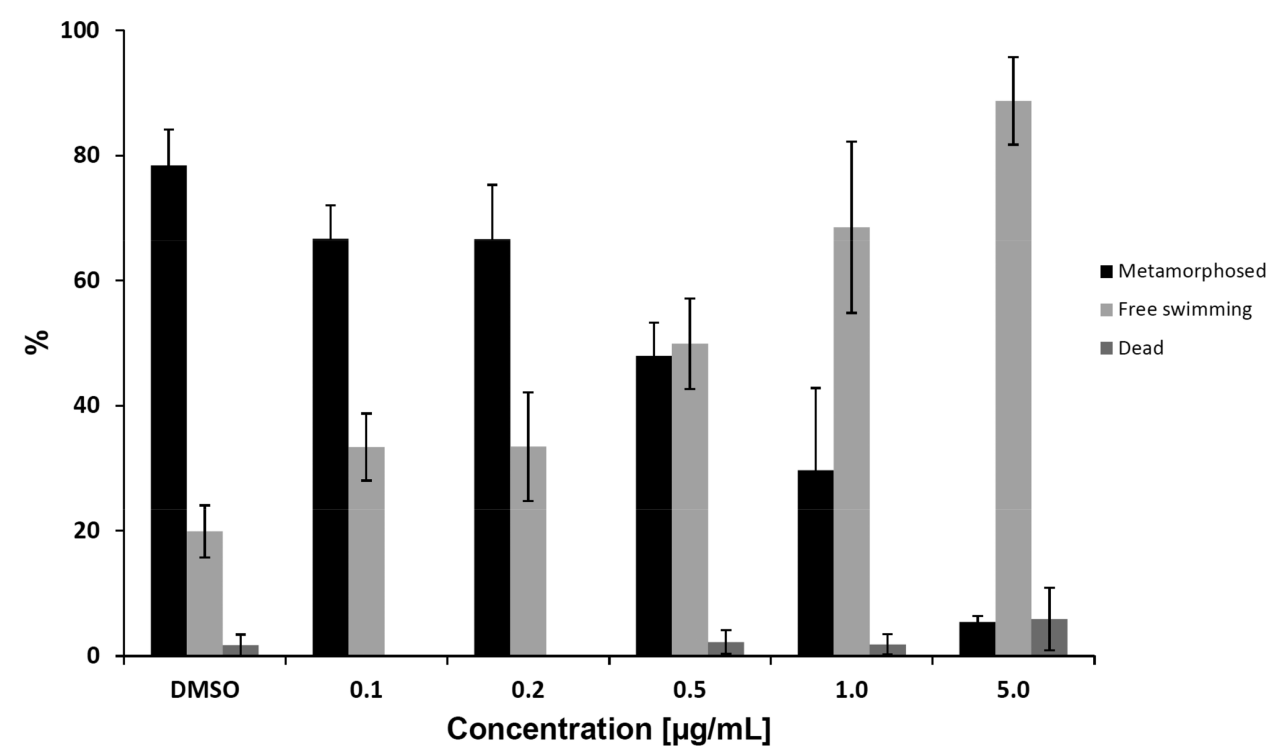

Figure 3. Dose response analysis $(0.1-5.0 \mu \mathrm{g} / \mathrm{mL})$ of $9 \mathrm{~d}$ on the settlement inhibition of $A$. improvisus cyprid larvae presented as percentages of settled (black columns), free swimming (light gray columns), and dead cyprids (dark gray columns) and given as means \pm standard error $(n=4)$. DMSO $(0.1 \%, \mathrm{v} / \mathrm{v})$ in filtered seawater was used as the negative control.

The current library was composed of compounds probing the effects of basicity and hydrogen bonding capacity of the cationic $\mathrm{arm}^{42}$ and also the distance between the brominated indole and the cationic charge. Several structure activity relationship studies on these specific functionalities and properties have been described for related MNPs ${ }^{17,43}$ and natural antifoulants. ${ }^{35,37,44}$ In Nature, most of these MNPs resemble a dipeptide in size and this library contain compounds within that size span with a number of shorter analogues. The active compounds 1, 9c, and 9d share several structural features. They all bear guanidine functionalities, and they all represent the longest compounds in the libraries with either five or six methylenes in the alkane linker. 9d is the longest compound in the study and also the most active one. The shorter guanidine bearing compounds $9 a$ and $9 \mathbf{b}$ are inactive as are the primary amines $\mathbf{8 a}-\mathbf{8 e}$, indicating that the increased basicity and hydrogen bonding capacity is essential for activity. ${ }^{42}$ This correlates well with related antifouling MNPs which commonly display a guanidine or a guanidine derivative. ${ }^{15,16,22}$ Compound 10, which displays a cationic quaternary ammonium group, is inactive. The $N$-methylated $8 \mathbf{e}$ represents an amine version of the highly active $\mathbf{9 d}$ but is inactive and illustrates how potential benefits arising from the $\mathrm{N}$-methylation is not sufficient in the absence of a guanidine functionality. Like all the compounds in the library, the indole motifs of $9 \mathrm{c}$ and $9 \mathrm{~d}$ are linked with the cationic arm with an amide bond as opposed to the natural 1,2,4-oxadiazole ring found in 1 . Both 9c and 9d display higher antifouling activity than 1, which illustrates that the 1,2,4-oxadiazole ring is not essential for activity if sufficient linker length and basicity is provided. This is an important observation and many studies on analogues of $\mathbf{1}$ in medically relevant screens have incorporated the synthesis of the 1,2,4-oxadiazole ring system into the library of screened compounds. ${ }^{32,33}$ Our studies suggest that significantly simplified analogues can be used to yield bioactive compounds with even improved activity. Collectively, the barnacle cyprid screen highlights that $\mathbf{1}$ is a potent natural antifoulant and that the scaffold can be used to generate simpler and improved synthetic analogues. The activity is linked to the size of the compound and to the basicity of the cationic group and the study demonstrates that active analogues can be prepared in the absence of the constrained 1,2,4-oxadiazole ring.

Coating Development. Given the high and repelling activity of 9d, it was decided to evaluate the ability of the compound to inhibit fouling in field immersion experiments. Such an experiment would also establish the general antifouling potential of the compound as the natural biofouling consortium contains microfoulers such as marine bacteria, micro- and macroalgae, and other potential macrofoulers in addition to barnacles. Many studies are published on antifouling experiments performed in laboratory bioassay settings but it is often highly speculative to conclude about the repelling potential of a compound or coating without access to data from field experiments. ${ }^{45}$ In addition, the search for new environmentally friendly, cost-effective, and legally acceptable ways of preventing growth of marine organisms on marine materials is urgent, as reviewed by Ciriminna ${ }^{46}$ and Kyei. ${ }^{47}$ To generate a coating suited for field studies, a previously developed biodegradable poly $(\varepsilon$-caprolactone-co- $\delta$ valerolactone) (80:20) polymer for antifouling applications was prepared and solubilized in xylene. ${ }^{48}$ Compound $9 \mathrm{~d}$ was added to the polymer, and $200 \mu \mathrm{m}$ thick polymer coatings were prepared on PVC panels, which were submerged for 84 days at a depth of $1 \mathrm{~m}$ in the port of Kernével in Lorient, France during the summer. The panels were regularly investigated for growth during the 84-day study, and the growth on the panels during the period is shown in Figure 4.

After 84 days the panels were removed from the water and the growth was assessed using confocal laser scanning microscopy (CLSM). On a macroscopic level no obvious differences between the different panels can be observed. No pronounced "edge effects", often observed during evaluation novel antifouling coatings, were seen on the treated panels either. ${ }^{49}$ Growth was observed on the treated panels after 28 days, while the control panels displayed growth after 14 days. This small difference however disappears with time. At the end of the experiments, the panels are seemingly covered to a 


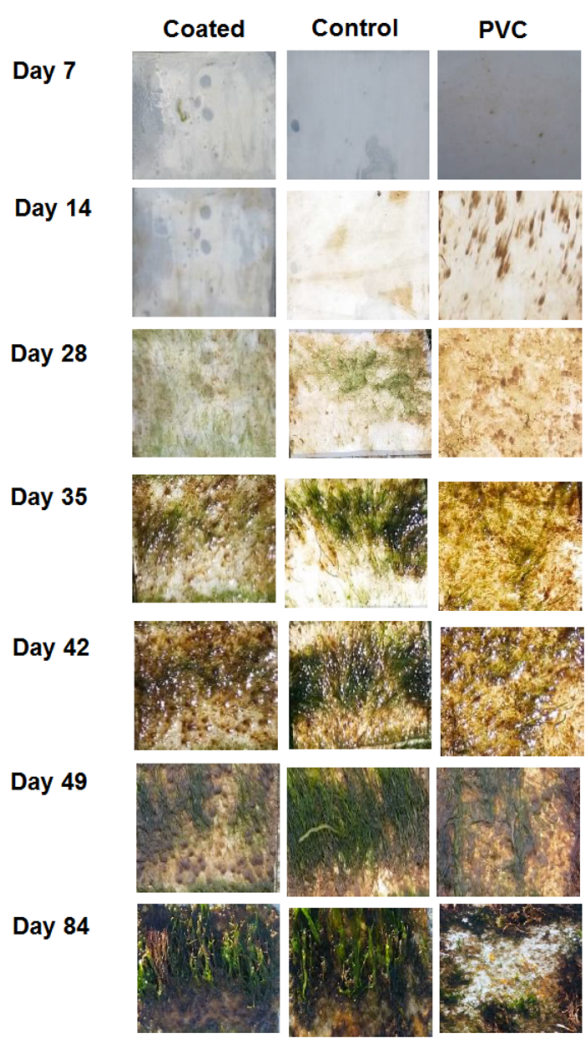

Figure 4. Results from the field trials illustrating the buildup of biofouling communities. Left column: 9d containing coating applied to PVC panel, center column: negative control coating without $9 \mathrm{~d}$ on PVC panel, right column: control PVC panel without any coating.

similar extent with a layer of biofouling organisms, the bulk of which appear to be chlorophycea (Ulva intestinalis) and phaeophycea macroalgae. It is not surprising to find such organisms on the panels as the formulation did not contain any photosynthesis inhibitors such as commercial herbicides. No barnacles were observed on any of the panels making assessments of the potential repelling effect of $9 d$ on the barnacle settlement inconclusive. The reproductive period of A. improvisus is mainly from May to September and the presence of free swimming cyprids occurs during this period. ${ }^{41}$ The reason for the general low settlement of barnacles during the experimental period is thus likely coupled with unexpected seasonal or local variability in free swimming cyprids and not due to specific repelling effects from the different panels and their coatings. CLSM analysis of the biofilms however revealed differences between the coatings as displayed in Figure 5.

The different staining methods employed allowed quantification of both marine bacteria and microalgae. Clear differences are seen between the coating incorporation 9d and the control coating. ${ }^{50}$ The coating incorporating 9d displays both lower coverage and biovolumes of bacteria (3fold) and microalgae (6-fold), suggesting that 9d also displays potent antifouling activities against marine microfoulers. The recorded reduction in biofilm establishment was observed at lower concentrations (in the coating) than those described for dibromohemibastadin-1 in vitro ${ }^{50}$ and also correlates well with in situ studies up to 35 days. ${ }^{51}$ Also in those recent studies, a more pronounced effect was seen on microalgal biofilm formation than for bacterial biofilms. ${ }^{51}$ Our current study shows that this effect persists for up to 84 days for 9d. Related compounds such as the synaxozolidiones ${ }^{5}$ and ianthelline ${ }^{15}$ are powerful inhibitors of the microfouling biofilm with $\mathrm{IC}_{50}$ values down to $10 \mathrm{ng} / \mathrm{mL}$ reported, which is 2 orders of magnitude lower than the concentration of $9 \mathrm{~d}$ in the coating. This illustrates how this class of compounds are often highly repelling against both micro- and macrofoulers. In parallel, while studies are ongoing on evaluating extracts of marine organisms to generate effective marine antifouling coatings, ${ }^{49}$ a focus on single compounds of known concentrations provides a more extensive understanding of the potency and mode of action. Being able to generate functional and environmentally benign coatings based on natural products or simplified synthetic mimics has been heralded as a promising way toward a new generation of antifouling coating technologies, ${ }^{47}$ and our work sheds additional light on the performance of these compounds and materials in vitro and in the field.

\section{CONCLUSIONS}

The antifouling potential of the MNP phidianidine A (1) has been established, and our study illustrates that $\mathbf{1}$ is a potent, nontoxic inhibitor of barnacle cyprid metamorphosis. Structure-activity studies employing simplified synthetic analogues illustrate that the antifouling activity against $A$. improvisus barnacles can be tuned, and optimized analogues can readily be prepared while excluding the 1,2,4-oxadiazole ring. A promising antifouling lead was identified (9d), and it was incorporated into an antifouling coating and evaluated in field trials for 84 days. A strong reduction in the settlement of microfouling organisms was shown, illustrating that the lead analogue also is a powerful inhibitor of microfouling. The effect on barnacle settlement in the field was inconclusive because of low amounts of naturally free-swimming barnacle cyprids during the field experiments. The current study sheds additional light on the structural motif of MNPs governing slow-moving or sessile marine organism protection against colonizing organisms and illustrates how these compounds can be significantly structurally simplified with maintained or even improved bioactivities.

\section{EXPERIMENTAL SECTION}

IR spectra were obtained on an Agilent Technologies Cary 630 FTIR spectrometer. ${ }^{1} \mathrm{H}$ and ${ }^{13} \mathrm{C}$ NMR spectra were recorded at ambient temperature at a frequency of 400 and $101 \mathrm{MHz}$, respectively on a Bruker spectrometer. The chemical shifts are reported in ppm and are referenced to the relevant solvent peak: $\mathrm{CDCl}_{3}$ at $\delta_{\mathrm{H}} 7.26$ and $\delta_{\mathrm{C}}$ 77.16; $\mathrm{CD}_{3} \mathrm{OD}$ at $\delta_{\mathrm{H}} 3.31$ and $\delta_{\mathrm{C}} 49.0 ;\left(\mathrm{CD}_{3}\right)_{2} \mathrm{SO}$ at $\delta_{\mathrm{H}} 2.50$ and $\delta_{\mathrm{C}}$ $39.5 \mathrm{ppm}$. High-resolution mass spectra (HRMS) were recorded using $\mathrm{MeOH}$ solution on LTQ Orbitrap XL in either positive or negative electrospray ionization (ESI) modes. TLC was performed on Merck silica gel 60 F254 plates, using UV light at $254 \mathrm{~nm}$, and PMA staining followed by heating for detection. Flash column chromatography was performed by using the indicated solvent system and silica gel $(40-63 \mu \mathrm{m})$. Microwave reactions were performed in $20 \mathrm{~mL}$ vials using a Discover SP from CEM using an Anton Parr Monowave 300 instrument. All reagents and solvents were purchased commercially and used directly without any further purification.

Synthesis. Phidianidine A (1). A sample of phidianidine (1) was prepared for biological testing according to literature procedures. ${ }^{38,52}$ The substituted 1,2,4-oxadiazole ring of 1 was prepared via the route described for the synthesis of phidianidine by Manzo et al. ${ }^{52}$ from $N$ Boc-1-amino-5-[(E)-2-hydroxyguanidino]-pentane and 6-bromo-3indoleacetic acid ethyl ester and was subsequently guanidylated with $N, N^{\prime}$-di-Boc- $1 H$-pyrazole-1-carboxamidine according to Lin and Snider. ${ }^{38}$ Compound 1 was prepared in $28 \%$ yield ( 2 steps) with spectral data matching those previously reported. ${ }^{1} \mathrm{H}$ NMR $(400$ $\mathrm{MHz}$, Methanol- $\left.d_{4}\right) \delta 7.56-7.51(\mathrm{~m}, 1 \mathrm{H}), 7.48-7.42(\mathrm{~m}, 1 \mathrm{H}), 7.24$ 
A

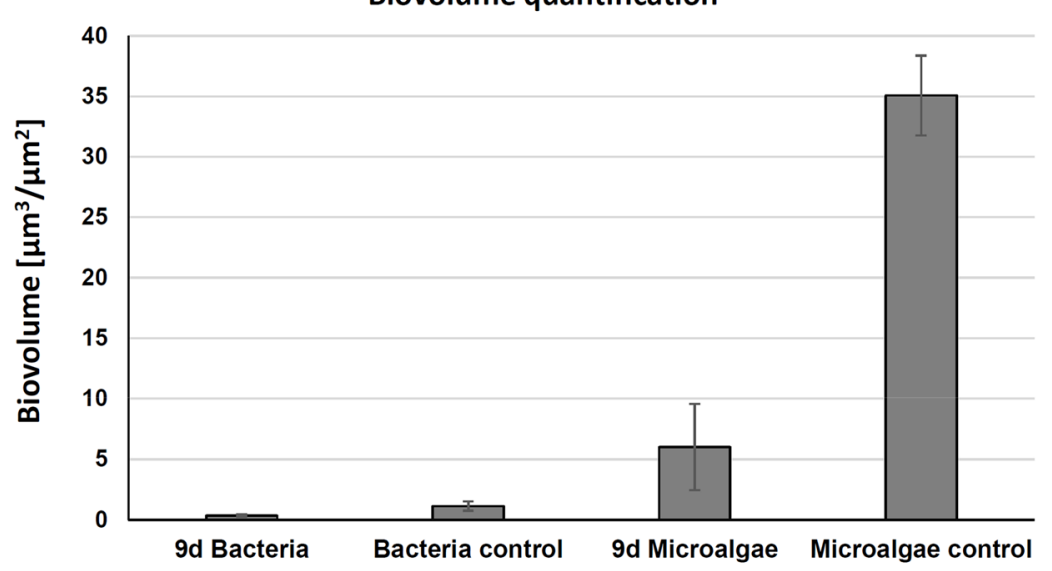

B
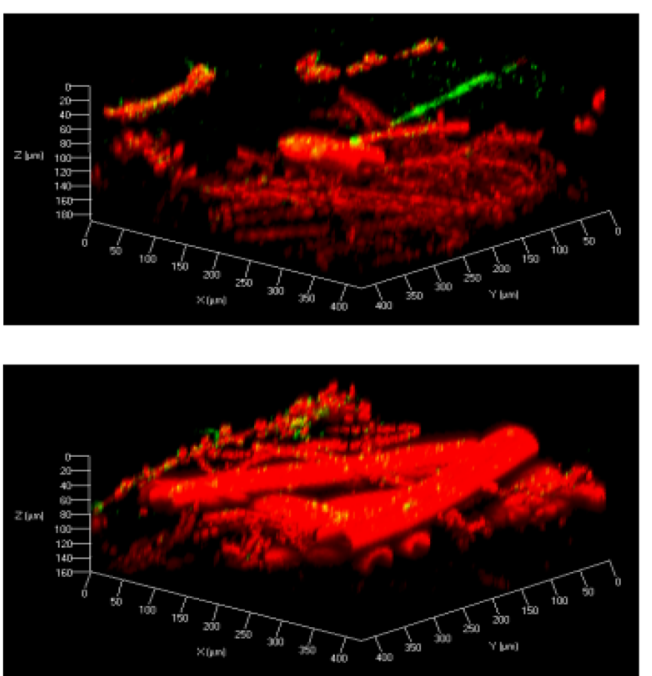
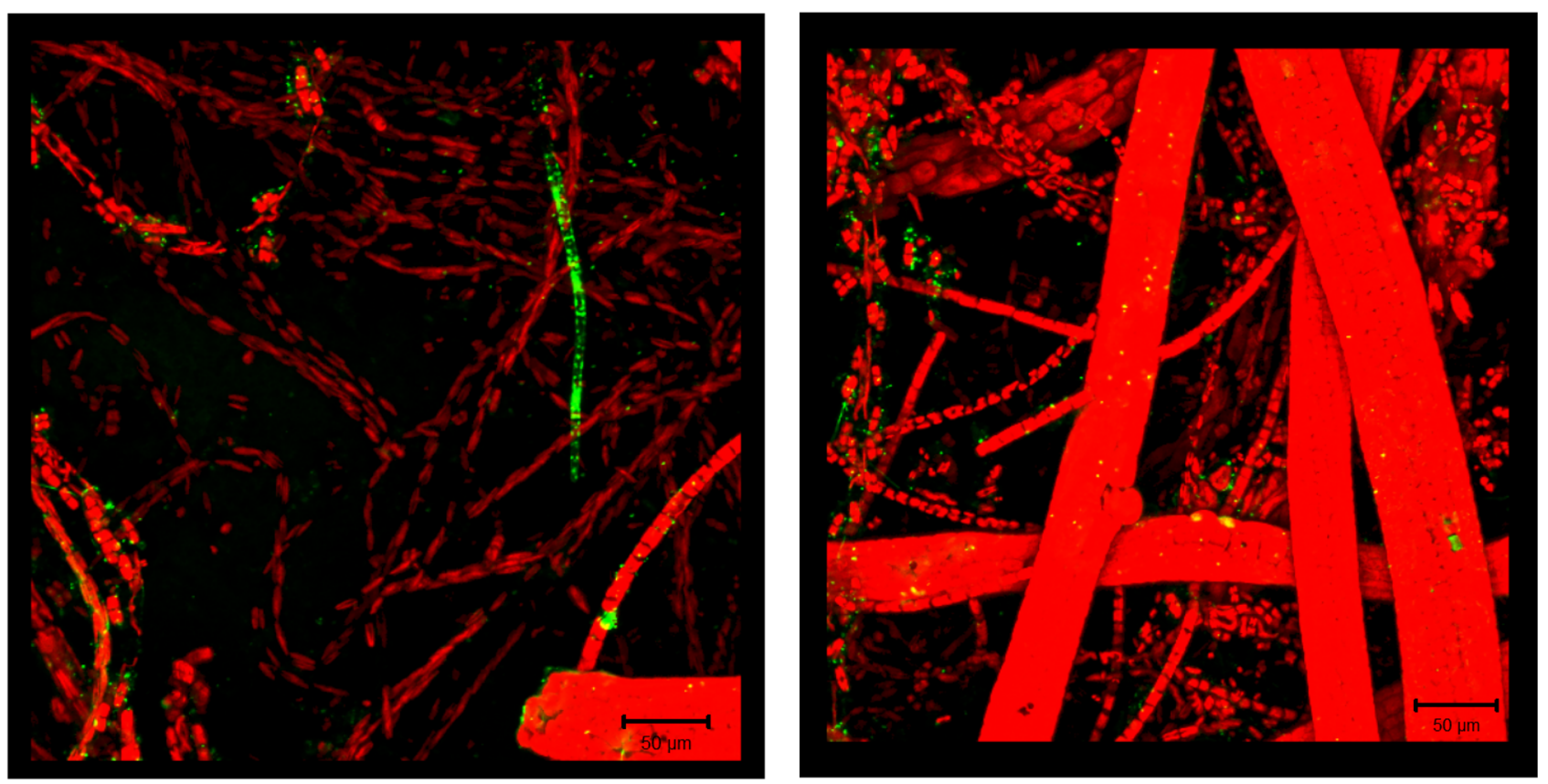

Figure 5. Upper row: quantification of the biovolumes $\left(\mu \mathrm{m}^{3} / \mu \mathrm{m}^{2}\right)$ of adhered bacteria and microalgae after 84 days immersion (A) and CLSM images used to assess the volume of the biofilms (B). Bottom row illustrates a top view of the formed biofilm on the surfaces coated with $9 \mathbf{d}$ (left) and the control varnish (right).

(t, $J=0.9 \mathrm{~Hz}, 1 \mathrm{H}), 7.13(\mathrm{dd}, J=8.5,1.8 \mathrm{~Hz}, 1 \mathrm{H}), 4.20(\mathrm{~d}, J=0.8 \mathrm{~Hz}$, $2 \mathrm{H})$, 3.19-3.09 (m, 4H), $1.66-1.54(\mathrm{~m}, 4 \mathrm{H}), 1.48-1.37(\mathrm{~m}$, $2 \mathrm{H}) .{ }^{13} \mathrm{C}$ NMR $\left(101 \mathrm{MHz}\right.$, Methanol- $\left.d_{4}\right) \delta 178.98,170.10,158.63$, $138.89,127.16,125.71,123.23,120.82,116.18,115.30,108.68,43.77$, 42.35, 29.74, 29.51, 24.90, 23.90. FTMS $m / z 420.1131[\mathrm{M}+\mathrm{H}]^{+}$ (calcd for $\mathrm{C}_{17} \mathrm{H}_{23}{ }^{79} \mathrm{BrN}_{7} \mathrm{O}^{+}, 420.1142$ ).

2-(6-Bromo-1H-indol-3-yl)-2-oxoacetic Acid (3). To a solution of 6-bromoindole ( $1.00 \mathrm{~g}, 5.1 \mathrm{mmol}, 1.0$ equiv) in diethyl ether $(20 \mathrm{~mL})$ was added oxalyl chloride $(0.89 \mathrm{~mL}, 10.2 \mathrm{mmol}, 2.0$ equiv). The solution was stirred at room temperature (rt) for $45 \mathrm{~min}$. Water $(0.5$ $\mathrm{mL}, 27.8 \mathrm{mmol}, 5.0$ equiv) was carefully added to the solution, followed by diethyl ether $(50 \mathrm{~mL})$. The resulting mixture was stirred for $30 \mathrm{~min}$, filtered, washed with diethyl ether, and dried under vacuum to afford 3 as a yellow powder $(1.05 \mathrm{~g}, 77 \%)$. IR $\left(\mathrm{cm}^{-1}\right)$. $3167,3146,1722,1626,1410,1227,1134,888,795,754,683 .{ }^{1} \mathrm{H}$ NMR (400 MHz, DMSO- $\left.d_{6}\right) \delta 13.66(\mathrm{~s}, 1 \mathrm{H}), 12.52(\mathrm{~s}, 1 \mathrm{H}), 8.49(\mathrm{~d}$, $J=3.3 \mathrm{~Hz}, 1 \mathrm{H}), 8.30(\mathrm{~d}, J=2.0 \mathrm{~Hz}, 1 \mathrm{H}), 7.52(\mathrm{~d}, J=8.6 \mathrm{~Hz}, 1 \mathrm{H})$, $7.42(\mathrm{dd}, J=8.6,2.0 \mathrm{~Hz}, 1 \mathrm{H}) .{ }^{13} \mathrm{C}$ NMR $\left(101 \mathrm{MHz}, \mathrm{DMSO}-d_{6}\right) \delta$ $180.6,164.8,139,135.5,127.4,126.3,123.2,115.5,114.8,111.8$.

FTMS $m / z$ 265.9455 $[\mathrm{M}-\mathrm{H}]^{-}$(calcd for $\mathrm{C}_{10} \mathrm{H}_{5}{ }^{79} \mathrm{BrNO}_{3}^{-}$, 265.9458).

2-(6-Bromo-1H-indol-3-yl)acetic Acid (4). To a microwave-vial equipped with a stir bar were added 3 ( $1.00 \mathrm{~g}, 3.74 \mathrm{mmol}, 1.0$ equiv), 2-ethoxyethanol $(10 \mathrm{~mL})$, and hydrazine $(0.91 \mathrm{~mL}, 18.73 \mathrm{mmol}, 5.0$ equiv). The vial was sealed and stirred for $15 \mathrm{~min}$ at $80{ }^{\circ} \mathrm{C}$ under microwave irradiation. Sodium methoxide $(1.84 \mathrm{~g}, 34.1 \mathrm{mmol}, 10.0$ equiv) was then added, and the reaction mixture resealed and stirred for $1 \mathrm{~h}$ at $160{ }^{\circ} \mathrm{C}$ under microwave irradiation before being quenched with $4 \mathrm{M} \mathrm{HCl}(20 \mathrm{~mL}), \mathrm{H}_{2} \mathrm{O}(20 \mathrm{~mL})$, and EtOAc $(50 \mathrm{~mL})$; extracted with EtOAc $(2 \times 20 \mathrm{~mL})$; dried over $\mathrm{Na}_{2} \mathrm{SO}_{4}$; and the solvent removed under reduced pressure. The crude product was purified by silica gel column chromatography $[($ EtOAc $+1 \%$ AcOH: $n$-heptane, 4:6)] to afford 4 as a pale yellow solid $(0.76 \mathrm{~g}$, $80 \%) . \mathrm{R}_{f}=0.125$ [(EtOAc: $n$-heptane, 1:1)]. IR $\left(\mathrm{cm}^{-1}\right) .3417,2933$, 2895, 2117, 1693, 1402, 1223, 1097, 866, 803, 773, 695. ${ }^{1} \mathrm{H}$ NMR 
$\left(400 \mathrm{MHz}\right.$, Methanol- $\left.d_{4}\right) \delta 7.68(\mathrm{~d}, J=1.8 \mathrm{~Hz}, 1 \mathrm{H}), 7.26(\mathrm{~d}, J=8.6$ $\mathrm{Hz}, 1 \mathrm{H}), 7.20-7.16(\mathrm{~m}, 2 \mathrm{H}), 3.69(\mathrm{~s}, 2 \mathrm{H}) .{ }^{13} \mathrm{C}$ NMR (101 MHz, Methanol- $\left.d_{4}\right) \delta 176.1,136.6,130.4,126.2,125.2,122.2,113.9,113$, 108.8, 31.8. FTMS $m / z 251.9670[\mathrm{M}-\mathrm{H}]^{-}\left(\right.$calcd for $\mathrm{C}_{10} \mathrm{H}_{7}{ }^{79} \mathrm{BrNO}_{2}^{-}$, 251.9666)

Monoboc Protected Diamines $(\mathbf{6} \boldsymbol{a}-\boldsymbol{d})$. Monoboc protected amines $6 \mathbf{a}-\mathbf{d}$ were prepared using standard protocols. ${ }^{53}$ The synthesis of compound $\mathbf{6 d}$ is provided as a representative example.

tert-Butyl-(6-aminohexyl)carbamate (6d). To a solution of 1,5diaminohexane $\left(5.00 \mathrm{~g}, 43.03 \mathrm{mmol}, 4.0\right.$ equiv) in dioxane: $\mathrm{H}_{2} \mathrm{O}(9: 1$, $50 \mathrm{~mL}$ ) was added dropwise a solution of di-tert-butyl dicarbonate (2.47 mL, $10.76 \mathrm{mmol}, 1.0$ equiv) in dioxane: $\mathrm{H}_{2} \mathrm{O}(9: 1,50 \mathrm{~mL})$ over $3 \mathrm{~h}$. The resulting mixture was stirred at rt overnight. The solvent was removed under reduced pressure and the residue was suspended in $\mathrm{H}_{2} \mathrm{O}(50 \mathrm{~mL})$ and filtered. The filtrate was then extracted with $\mathrm{CH}_{2} \mathrm{Cl}_{2}(3 \times 20 \mathrm{~mL})$, washed with $\mathrm{H}_{2} \mathrm{O}$, dried over $\mathrm{Na}_{2} \mathrm{SO}_{4}$, filtered, and the solvent removed under reduced pressure to afford $\mathbf{6 d}$ as a white oil (6.6 g, 71\%). IR ( $\left.\mathrm{cm}^{-1}\right)$. 3361, 2977, 2929, 2858, 1696, $1529,1369,1253,1171 .{ }^{1} \mathrm{H}$ NMR $(400 \mathrm{MHz}$, Chloroform- $d) \delta 4.73$ $(\mathrm{s}, 1 \mathrm{H}), 3.02(\mathrm{q}, J=6.8 \mathrm{~Hz}, 2 \mathrm{H}), 2.62-2.57(\mathrm{~m}, 2 \mathrm{H}), 1.45-1.28(\mathrm{~m}$, $13 \mathrm{H}), 1.28-1.21(\mathrm{~m}, 4 \mathrm{H}), 1.04(\mathrm{~s}, 2 \mathrm{H}) .{ }^{13} \mathrm{C}$ NMR (101 MHz, Chloroform-d) $\delta$ 156, 78.8, 42.1, 40.4, 30, 28.4, 26.7, 26.6, 26.5. FTMS $m / z 217.1924[\mathrm{M}+\mathrm{H}]^{+}$(calcd for $\left.\mathrm{C}_{11} \mathrm{H}_{25} \mathrm{~N}_{2} \mathrm{O}_{2}{ }^{+}, 217.1911\right)$.

tert-Butyl-(6-(methylamino)hexyl)carbamate (7). To a solution of 6-hydroxy-1-hexylamine $(2.80 \mathrm{~g}, 24 \mathrm{mmol})$ in $\mathrm{CH}_{2} \mathrm{Cl}_{2}(50 \mathrm{~mL})$, was added di-tert-butyl dicarbonate $(5.2 \mathrm{~g}, 4.7 \mathrm{mmol})$. Triethylamine $(3.7 \mathrm{~mL})$ was added dropwise, and the reaction stirred at $\mathrm{rt}$ for $2 \mathrm{~h}$. The reaction mixture was then washed with $\mathrm{H}_{2} \mathrm{O}(20 \mathrm{~mL})$ and extracted with $\mathrm{CH}_{2} \mathrm{Cl}_{2}(2 \times 50 \mathrm{~mL})$. The solvent was evaporated to afford $\mathrm{N}$-(tert-butoxycarbonyl)-6-hydroxy-1-hexylamine (4.95 g, 95\%) as pale-white solid, which was used without further purification. ${ }^{1} \mathrm{H}$ NMR (400 MHz, Chloroform- $d$ ) $\delta 4.56(\mathrm{~s}, 1 \mathrm{H}), 3.61(\mathrm{td}, J=6.5,5.3$ $\mathrm{Hz}, 2 \mathrm{H}), 3.09(\mathrm{q}, J=6.7 \mathrm{~Hz}, 2 \mathrm{H}), 1.77(\mathrm{t}, J=5.5 \mathrm{~Hz}, 1 \mathrm{H}), 1.59-1.51$ $(\mathrm{m}, 2 \mathrm{H}), 1.50-1.44(\mathrm{~m}, 2 \mathrm{H}), 1.42(\mathrm{~s}, 9 \mathrm{H}), 1.35$ (ddd, $J=14.9,9.0$, $3.9 \mathrm{~Hz}, 4 \mathrm{H}) .{ }^{13} \mathrm{C}$ NMR (101 MHz, Chloroform-d) $\delta$ 156.1, 79.1, 62.6, 46.0, 40.4, 32.6, 31.2, 30.1, 28.4, 26.4, 25.3. To a $0{ }^{\circ} \mathrm{C}$ solution of $\mathrm{N}$ (tert-butoxycarbonyl)-6-hydroxy-1-hexylamine $(2.0 \mathrm{~g}, 9.2 \mathrm{mmol}, 1.0$ equiv) in $\mathrm{CH}_{2} \mathrm{Cl}_{2}(20 \mathrm{~mL})$ was added methane sulfonyl chloride (0.85 mL, $9.3 \mathrm{mmol}, 1.1$ equiv). Triethylamine $(1.5 \mathrm{~mL}, 9.4 \mathrm{mmol}$, 1.2 equiv) was added dropwise to the $0{ }^{\circ} \mathrm{C}$ solution, and then the reaction was stirred at $\mathrm{rt}$ for $5 \mathrm{~h}$. The solvents were removed under reduced pressure to afford $N$-(tert-butoxycarbonyl)-6((methanesulfonyl)oxy)hexylamine $(2.65 \mathrm{~g}, 97 \%)$ as white crystalline solid, which was used without further purification. ${ }^{1} \mathrm{H}$ NMR (400 $\left.\mathrm{MHz}, \mathrm{CDCl}_{3}\right) \delta 4.18(\mathrm{t}, J=6.5 \mathrm{~Hz}, 2 \mathrm{H}), 3.07(\mathrm{t}, J=7.0 \mathrm{~Hz}, 2 \mathrm{H})$, $2.97(\mathrm{~s}, 3 \mathrm{H}), 1.78-1.65(\mathrm{~m}, 2 \mathrm{H}), 1.51-1.43(\mathrm{~m}, 2 \mathrm{H}), 1.40(\mathrm{~s}, 9 \mathrm{H})$, 1.39-1.27 (m, 4H). ${ }^{13} \mathrm{C}$ NMR (101 MHz, $\left.\mathrm{CDCl}_{3}\right) \delta 156.0,79.1$, $70.0,37.3,29.9,29.0,28.4,26.2,25.1$. To a solution of $\mathrm{N}$-(tertbutoxycarbonyl)-6-((methanesulfonyl)oxy)hexylamine (2.6 g, 8.97 mmol, 1.0 equiv) in dioxane $(20 \mathrm{~mL})$ was slowly added aqueous methylamine $(20 \mathrm{~mL}, 40 \%, 60$ equiv). The mixture was stirred at 60 ${ }^{\circ} \mathrm{C}$ for $1 \mathrm{~h}$ and monitored by TLC $\left(\mathrm{CH}_{2} \mathrm{Cl}_{2} / \mathrm{MeOH} / \mathrm{NH}_{3}\right.$ aq., 9.0:0.9:0.1, PMA stain), concentrated under reduced pressure to afford the product 7 as a light beige solid (1.2 g, 58\%), which was used without further purification. ${ }^{1} \mathrm{H}$ NMR $\left(400 \mathrm{MHz}, \mathrm{CDCl}_{3}\right) \delta 3.06$ $(\mathrm{t}, J=7.0 \mathrm{~Hz}, 2 \mathrm{H}), 2.97-2.85(\mathrm{~m}, 3 \mathrm{H}), 2.65(\mathrm{t}, J=5.5 \mathrm{~Hz}, 2 \mathrm{H}), 1.83$ $(\mathrm{q}, J=7.6 \mathrm{~Hz}, 2 \mathrm{H}), 1.41(\mathrm{~s}, 15 \mathrm{H}) \cdot{ }^{13} \mathrm{C}$ NMR $\left(101 \mathrm{MHz}, \mathrm{CDCl}_{3}\right) \delta$ $156.1,79.1,49.2$, 38.6, 32.9, 29.7, 29.3, 28.4, 26.1, 26.0, 25.7. FTMS $m / z 231.2061[\mathrm{M}+\mathrm{H}]^{+}$(calcd for $\left.\mathrm{C}_{12} \mathrm{H}_{27} \mathrm{~N}_{2} \mathrm{O}_{2}{ }^{+}, 231.2067\right)$.

$\mathrm{N}$-(3-Aminopropyl)-2-(6-bromo-1H-indol-3-yl)acetamide (8a). To a solution of $4\left(1.00 \mathrm{~g}, 3.94 \mathrm{mmol}, 1.0\right.$ equiv) in $\mathrm{CH}_{2} \mathrm{Cl}_{2}(10$ $\mathrm{mL})$ were added DIPEA $(0.75 \mathrm{~mL}, 4.33 \mathrm{mmol}, 1.1$ equiv) and HATU (1.497 g, $3.94 \mathrm{mmol}, 1.0$ equiv). The mixture was stirred at $\mathrm{rt}$ for 30 min. A solution 6a (0.755 g, $4.33 \mathrm{mmol}, 1.1$ equiv) in $\mathrm{CH}_{2} \mathrm{Cl}_{2}$ (10 $\mathrm{mL}$ ) was then added, and the resulting mixture was stirred at $\mathrm{rt}$ for 90 min. A solution of $\mathrm{CH}_{2} \mathrm{Cl}_{2}$ :TFA $(1: 1,20 \mathrm{~mL})$ was directly added to the reaction mixture and stirred for $3 \mathrm{~h}$ at $\mathrm{rt}$. The dark brown solution was quenched with $\mathrm{H}_{2} \mathrm{O}(20 \mathrm{~mL})$ and the $\mathrm{pH}$ adjusted to 12 with 4 $\mathrm{M} \mathrm{NaOH}(35 \mathrm{~mL})$, extracted with $\mathrm{CH}_{2} \mathrm{Cl}_{2}(2 \times 20 \mathrm{~mL})$, dried over $\mathrm{Na}_{2} \mathrm{SO}_{4}$, filtered, and the solvent removed under reduced pressure.
The crude product was purified by silica gel column chromatography [ $\left(\mathrm{CH}_{2} \mathrm{Cl}_{2}: 100\right.$ to $\left.\left.\mathrm{MeOH}: 100\right)\right]$ to afford $8 \mathrm{a}$ as a light yellow oil $(0.89 \mathrm{~g}, 73 \%) . \mathrm{R}_{f}=0.03[(\mathrm{MeOH}: 100)] . \mathrm{IR}\left(\mathrm{cm}^{-1}\right) .3253,2929$, $2869,2117,1640,1529,1454,1343,1227,1108,884,795 .{ }^{1} \mathrm{H}$ NMR $\left(400 \mathrm{MHz}\right.$, Methanol- $\left.d_{4}\right) \delta 7.71(\mathrm{~d}, J=1.9 \mathrm{~Hz}, 1 \mathrm{H}), 7.27(\mathrm{~d}, J=8.6$ $\mathrm{Hz}, 1 \mathrm{H}), 7.21-7.16(\mathrm{~m}, 2 \mathrm{H}), 3.59(\mathrm{~s}, 2 \mathrm{H}), 3.23(\mathrm{t}, J=6.7 \mathrm{~Hz}, 2 \mathrm{H})$, $2.57(\mathrm{t}, J=6.9 \mathrm{~Hz}, 2 \mathrm{H}), 1.60(\mathrm{p}, J=6.8 \mathrm{~Hz}, 2 \mathrm{H}) .{ }^{13} \mathrm{C}$ NMR $(101$ $\mathrm{MHz}$, Methanol- $\left.d_{4}\right) \delta 174.7,136.7,130.3,126.5,125.3,122,114$, 113.1, 109.4, 39.6, 37.8, 33.8, 33.3. FTMS $m / z 310.0567[\mathrm{M}+\mathrm{H}]^{+}$ (calcd for $\mathrm{C}_{13} \mathrm{H}_{17}{ }^{79} \mathrm{BrN}_{3} \mathrm{O}^{+}, 310.0550$ ).

$\mathrm{N}$-(4-Aminobutyl)-2-(6-bromo-1H-indol-3-yl)acetamide (8b). To a solution of $4(0.500 \mathrm{~g}, 2 \mathrm{mmol}, 1.0$ equiv $)$ in $\mathrm{CH}_{2} \mathrm{Cl}_{2}(7 \mathrm{~mL})$ were added DIPEA (0.38 mL, $2.2 \mathrm{mmol}, 1.1$ equiv) and HATU (0.760 g, 2 $\mathrm{mmol}, 1$ equiv). The mixture was stirred at $\mathrm{rt}$ for $30 \mathrm{~min}$. A solution of 6b $\left(0.414 \mathrm{~g}, 2 \mathrm{mmol}, 1.1\right.$ equiv) in $\mathrm{CH}_{2} \mathrm{Cl}_{2}(7 \mathrm{~mL})$ was then added, and the resulting mixture was stirred at room $\mathrm{rt}$ for $90 \mathrm{~min}$. A solution of $\mathrm{CH}_{2} \mathrm{Cl}_{2}$ :TFA $(1: 1,20 \mathrm{~mL})$ was directly added to the reaction mixture and it was stirred for $3 \mathrm{~h}$ at rt. The dark brown solution was quenched with $\mathrm{H}_{2} \mathrm{O}(20 \mathrm{~mL})$ and the $\mathrm{pH}$ adjusted to 12 with $4 \mathrm{M}$ $\mathrm{NaOH}(35 \mathrm{~mL})$, extracted with $\mathrm{CH}_{2} \mathrm{Cl}_{2}(2 \times 20 \mathrm{~mL})$, dried over $\mathrm{Na}_{2} \mathrm{SO}_{4}$, filtered, and the solvent removed under reduced pressure. The crude product was purified by silica gel column $\left[\left(\mathrm{CH}_{2} \mathrm{Cl}_{2}: 100\right.\right.$ to $\mathrm{MeOH}: 100)$ ] to afford $\mathbf{8 b}$ as a light yellow oily solid (0.28 $\mathrm{g}, 43 \%)$. $\mathrm{R}_{f}=0.03$ [(MeOH: 100)]. IR $\left(\mathrm{cm}^{-1}\right) .3249,2925,2858,2113,1640$, $1529,1454,1343,1227,1108,884,795 .{ }^{1} \mathrm{H}$ NMR (400 MHz, Methanol- $\left.d_{4}\right) \delta 7.72(\mathrm{~d}, J=1.8 \mathrm{~Hz}, 1 \mathrm{H}), 7.27(\mathrm{~d}, J=8.6 \mathrm{~Hz}, 1 \mathrm{H})$, $7.21-7.16(\mathrm{~m}, 2 \mathrm{H}), 3.59(\mathrm{~s}, 2 \mathrm{H}), 3.17(\mathrm{t}, J=6.7 \mathrm{~Hz}, 2 \mathrm{H}), 2.57(\mathrm{t}, J=$ $7.0 \mathrm{~Hz}, 2 \mathrm{H}), 1.51-1.35(\mathrm{~m}, 4 \mathrm{H}) .{ }^{13} \mathrm{C}$ NMR $\left(101 \mathrm{MHz}\right.$, Methanol- $\left.d_{4}\right)$ $\delta 174.5,136.7,130.3,126.5,125.2,122.1,114,113.1,109.5,42.1$, 40.3, 33.9, 30.9, 27.7. FTMS $\mathrm{m} / z 324.0713[\mathrm{M}+\mathrm{H}]^{+}$(calcd for $\left.\mathrm{C}_{14} \mathrm{H}_{19}{ }^{79} \mathrm{BrN}_{3} \mathrm{O}^{+}, 324.0706\right)$.

$\mathrm{N}$-(5-Aminopentyl)-2-(6-bromo-1H-indol-3-yl)acetamide (8c). To a solution of $4\left(1.00 \mathrm{~g}, 3.94 \mathrm{mmol}, 1.0\right.$ equiv) in $\mathrm{CH}_{2} \mathrm{Cl}_{2}$ (10 $\mathrm{mL})$ were added DIPEA ( $0.75 \mathrm{~mL}, 4.33 \mathrm{mmol}, 1.1$ equiv) and HATU (1.497 g, $3.94 \mathrm{mmol}, 1$ equiv). The mixture was stirred at $\mathrm{rt}$ for 30 min. A solution of $6 \mathrm{c}\left(0.876 \mathrm{~g}, 4.33 \mathrm{mmol}, 1.1\right.$ equiv) in $\mathrm{CH}_{2} \mathrm{Cl}_{2}(10$ $\mathrm{mL}$ ) was then added, and the resulting mixture was stirred at $\mathrm{rt}$ for 90 min. A solution of $\mathrm{CH}_{2} \mathrm{Cl}_{2}$ :TFA $(1: 1,20 \mathrm{~mL})$ was directly added to the reaction mixture and it was stirred for $3 \mathrm{~h}$ at $\mathrm{rt}$. The dark brown solution was quenched with $\mathrm{H}_{2} \mathrm{O}(20 \mathrm{~mL})$ and the $\mathrm{pH}$ adjusted to 12 with $4 \mathrm{M} \mathrm{NaOH}(35 \mathrm{~mL})$, extracted with $\mathrm{CH}_{2} \mathrm{Cl}_{2}(2 \times 20 \mathrm{~mL})$, dried over $\mathrm{Na}_{2} \mathrm{SO}_{4}$, filtered, and the solvent removed under reduced pressure. The crude product was purified by silica gel column chromatography $\left[\left(\mathrm{CH}_{2} \mathrm{Cl}_{2}: 100\right.\right.$ to $\left.\left.\mathrm{MeOH}: 100\right)\right]$ to afford $8 \mathrm{c}$ as a light yellow oily solid (0.92 g, 69\%). $\mathrm{R}_{f}=0.03$ [( $\left.\left.\mathrm{MeOH}: 100\right)\right]$. IR $\left(\mathrm{cm}^{-1}\right) .3242,2929,2858,2125,1640,1529,1439,1343,1227,1108$, 884, 795. ${ }^{1} \mathrm{H}$ NMR (400 MHz, Methanol- $\left.d_{4}\right) \delta 7.72(\mathrm{~d}, J=1.8 \mathrm{~Hz}$, $1 \mathrm{H}), 7.27(\mathrm{~d}, J=8.6 \mathrm{~Hz}, 1 \mathrm{H}), 7.22-7.15(\mathrm{~m}, 2 \mathrm{H}), 3.59(\mathrm{~s}, 2 \mathrm{H}), 3.17$ $(\mathrm{t}, J=6.9 \mathrm{~Hz}, 2 \mathrm{H}), 2.53(\mathrm{t}, J=7.0 \mathrm{~Hz}, 2 \mathrm{H}), 1.52-1.34(\mathrm{~m}, 4 \mathrm{H})$, $1.30-1.18(\mathrm{~m}, 2 \mathrm{H}) .{ }^{13} \mathrm{C}$ NMR (101 MHz, Methanol- $\left.d_{4}\right) \delta 174.4$ 136.7, 130.3, 126.5, 125.2, 122.1, 114, 113.1, 109.5, 42.4, 40.4, 33.9, 33.4, 30.2, 25.1. FTMS $m / z 338.0878[\mathrm{M}+\mathrm{H}]^{+}$(calcd for $\left.\mathrm{C}_{15} \mathrm{H}_{21}{ }^{79} \mathrm{BrN}_{3} \mathrm{O}^{+}, 338.0863\right)$.

$\mathrm{N}$-(6-Aminohexyl)-2-(6-bromo-1H-indol-3-yl)acetamide (8d). To a solution of $4\left(1.00 \mathrm{~g}, 3.94 \mathrm{mmol}, 1.0\right.$ equiv) in $\mathrm{CH}_{2} \mathrm{Cl}_{2}(10 \mathrm{~mL})$ were added DIPEA (0.75 mL, $4.33 \mathrm{mmol}, 1.1$ equiv) and HATU $(1.497 \mathrm{~g}, 3.94 \mathrm{mmol}, 1.0$ equiv). The mixture was stirred at $\mathrm{rt}$ for 30 min. A solution of $6 \mathbf{d}\left(0.937 \mathrm{~g}, 4.33 \mathrm{mmol}, 1.1\right.$ equiv) in $\mathrm{CH}_{2} \mathrm{Cl}_{2}(10$ $\mathrm{mL}$ ) was then added, and the resulting mixture was stirred at $\mathrm{rt}$ for 90 min. A solution of $\mathrm{CH}_{2} \mathrm{Cl}_{2}$ :TFA $(1: 1,20 \mathrm{~mL})$ was directly added to the reaction mixture and was stirred for $3 \mathrm{~h}$ at $\mathrm{rt}$. The dark brown solution was quenched with $\mathrm{H}_{2} \mathrm{O}(20 \mathrm{~mL})$ and the $\mathrm{pH}$ adjusted to 12 with $4 \mathrm{M} \mathrm{NaOH}(35 \mathrm{~mL})$, extracted with $\mathrm{CH}_{2} \mathrm{Cl}_{2}(2 \times 20 \mathrm{~mL})$, dried over $\mathrm{Na}_{2} \mathrm{SO}_{4}$, filtered, and the solvent removed under reduced pressure. The crude product was purified by silica gel column chromatography $\left[\left(\mathrm{CH}_{2} \mathrm{Cl}_{2}: 100\right.\right.$ to $\left.\left.\mathrm{MeOH}: 100\right)\right]$ to afford $\mathbf{8 d}$ as a light yellow oily solid $(0.23 \mathrm{~g}, 33 \%) . \mathrm{R}_{f}=0.03[(\mathrm{MeOH}: 100)]$. IR $\left(\mathrm{cm}^{-1}\right) .3238,2929,2858,2180,1644,1529,1439,1361,1227,1108$, 884, 795. ${ }^{1} \mathrm{H}$ NMR $\left(400 \mathrm{MHz}\right.$, Methanol- $\left.d_{4}\right) \delta 7.71(\mathrm{~d}, J=1.9 \mathrm{~Hz}$, $1 \mathrm{H}), 7.27(\mathrm{~d}, J=8.6 \mathrm{~Hz}, 1 \mathrm{H}), 7.21-7.16(\mathrm{~m}, 2 \mathrm{H}), 3.59(\mathrm{~s}, 2 \mathrm{H}), 3.16$ 
$(\mathrm{t}, J=6.9 \mathrm{~Hz}, 2 \mathrm{H}), 2.58(\mathrm{t}, J=7.2 \mathrm{~Hz}, 2 \mathrm{H}), 1.48-1.36(\mathrm{~m}, 4 \mathrm{H})$, $1.31-1.22(\mathrm{~m}, 4 \mathrm{H}) .{ }^{13} \mathrm{C}$ NMR $\left(101 \mathrm{MHz}\right.$, Methanol- $\left.d_{4}\right) \delta 174.4$, $136.8,130.3,126.5,125.2,122.1,114,113.1,109.5,42.3,40.4,38.9$, 33.9, 33.4, 30.3, 27.6. FTMS $m / z 352.1027[\mathrm{M}+\mathrm{H}]^{+}$(calcd for $\left.\mathrm{C}_{16} \mathrm{H}_{23}{ }^{79} \mathrm{BrN}_{3} \mathrm{O}^{+}, 352.1019\right)$.

$\mathrm{N}$-(6-Aminohexyl)-2-(6-bromo-1H-indol-3-yl)-N-methylacetamide (8e). To a solution of $4(0.560 \mathrm{~g}, 2.20 \mathrm{mmol}, 1.0$ equiv) in $\mathrm{CH}_{2} \mathrm{Cl}_{2}(10 \mathrm{~mL})$ were added DIPEA $(0.45 \mathrm{~mL}, 2.44 \mathrm{mmol}, 1.1$ equiv) and HATU (0.900 g, $2.20 \mathrm{mmol}, 1$ equiv). The mixture was stirred at rt for $30 \mathrm{~min}$. A solution of $7(0.550 \mathrm{~g}, 2.44 \mathrm{mmol}, 1.1$ equiv) in $\mathrm{CH}_{2} \mathrm{Cl}_{2}(10 \mathrm{~mL})$ was then added, and the resulting mixture was stirred at $\mathrm{rt}$ for overnight. A solution of $\mathrm{CH}_{2} \mathrm{Cl}_{2}$ :TFA (1:1, 20 $\mathrm{mL}$ ) was directly added to the reaction mixture and was stirred for $3 \mathrm{~h}$ at rt. The dark brown solution was quenched with $\mathrm{H}_{2} \mathrm{O}(20 \mathrm{~mL})$ and the $\mathrm{pH}$ adjusted to 12 with $4 \mathrm{M} \mathrm{NaOH}(35 \mathrm{~mL})$, extracted with $\mathrm{CH}_{2} \mathrm{Cl}_{2}(2 \times 20 \mathrm{~mL})$, dried over $\mathrm{Na}_{2} \mathrm{SO}_{4}$, filtered, and the solvent removed under reduced pressure. The crude product was purified by silica gel column chromatography $\left[\left(\mathrm{CH}_{2} \mathrm{Cl}_{2}: 100\right.\right.$ to $\mathrm{MeOH}$ : 100)] to afford 8e as a pale-yellow oil $(61 \mathrm{mg}, 8 \%){ }^{1} \mathrm{H}$ NMR $(400 \mathrm{MHz}$, Methanol- $\left.d_{4}\right) \delta 7.68-7.56(\mathrm{~m}, 1 \mathrm{H}), 7.15(\mathrm{ddt}, J=8.9,6.2,2.8 \mathrm{~Hz}$, $1 \mathrm{H}), 7.11-6.99(\mathrm{~m}, 2 \mathrm{H}), 3.80-3.59(\mathrm{~m}, 2 \mathrm{H}), 3.31-3.21(\mathrm{~m}, 2 \mathrm{H})$, $3.03-2.77(\mathrm{~m}, 3 \mathrm{H}), 2.56-2.41(\mathrm{~m}, 2 \mathrm{H}), 1.36-1.21(\mathrm{~m}, 4 \mathrm{H}), 1.14-$ $0.94(\mathrm{~m}, 4 \mathrm{H}) .{ }^{13} \mathrm{C}$ NMR $\left(101 \mathrm{MHz}\right.$, Methanol- $\left.d_{4}\right) \delta: 172.4,135.4$, $129.0,124.5,123.9,121.0,112.61,111.7,107.5,50.2,47.4,47.2,47.0$, 40.6, 35.0, 32.5, 31.1, 27.7, 26.6, 26.0. FTMS $m / z 366.1176[\mathrm{M}+\mathrm{H}]^{+}$ (calcd for $\left.\mathrm{C}_{17} \mathrm{H}_{25}{ }^{79} \mathrm{BrN}_{3} \mathrm{O}^{+}, 366.1176\right)$.

Amino-((3-(2-(6-bromo-1H-indol-3-yl)acetamido)propyl)amino)methaniminium 2,2,2-trifluoroacetate (9a). To a solution of 8 a (90 $\mathrm{mg}, 0.3 \mathrm{mmol}, 1.0$ equiv) and $N, N^{\prime}$-Di-Boc- $1 H$-pyrazole-1-carboxamidine $(0.18 \mathrm{~g}, 0.59 \mathrm{mmol}, 2.0$ equiv) in THF $(5 \mathrm{~mL})$ was added DIPEA ( $0.1 \mathrm{~mL}, 0.59 \mathrm{mmol}, 2.0$ equiv). The mixture was stirred at $\mathrm{rt}$ for $3 \mathrm{~h}$, quenched with $\mathrm{H}_{2} \mathrm{O}(10 \mathrm{~mL})$, extracted with diethyl ether (2 $\times 10 \mathrm{~mL})$, washed with sat. $\mathrm{NaHCO}_{3}$ and brine $(10 \mathrm{~mL})$, dried over $\mathrm{Na}_{2} \mathrm{SO}_{4}$, and concentrated. The crude product was purified on silica gel column chromatography [(EtOAc:Hept-n, 6:4)] to give the intermediate as a transparent oil $(0.15 \mathrm{~g}, 91 \%) . \mathrm{R}_{f}=0.21$ [(EtOAc:Hept-n, 4:1)]. ${ }^{1} \mathrm{H}$ NMR $\left(400 \mathrm{MHz}\right.$, Methanol- $\left.d_{4}\right) \delta 7.83$ (broad s, $1 \mathrm{H}), 7.31-7.14(\mathrm{~m}, 3 \mathrm{H}), 3.64(\mathrm{~s}, 2 \mathrm{H}), 3.39-3.29(\mathrm{~m}, 4 \mathrm{H}$, solvent), 3.22 (broad s, $2 \mathrm{H}), 1.60-1.36(\mathrm{~m}, 20 \mathrm{H}) .{ }^{13} \mathrm{C}$ NMR $(101$ $\mathrm{MHz}$, Methanol-d4) $\delta$ 174.4, 164.4, 157.9, 153.9, 136.6, 130.2, 126.4, 125.2, 122.2, 114, 113.1, 109.5, 84.3, 80.4, 38.8, 37.3, 34.1, 30.1, 28.6, 28.2. FTMS $m / z 552.1878[\mathrm{M}+\mathrm{H}]^{+}$(calcd for $\mathrm{C}_{24} \mathrm{H}_{35}{ }^{79} \mathrm{BrN}_{5} \mathrm{O}_{5}{ }^{+}$, $552.1816)$

The intermediate ( $0.15 \mathrm{~g}, 0.27 \mathrm{mmol}, 1.0$ equiv) was dissolved in $\mathrm{CH}_{2} \mathrm{Cl}_{2}(5 \mathrm{~mL})$ and a solution of TFA: $\mathrm{CH}_{2} \mathrm{Cl}_{2}(1: 1,10 \mathrm{~mL})$ was added. The reaction mixture was stirred at rt for $2 \mathrm{~h}$, quenched with $\mathrm{H}_{2} \mathrm{O}$, extracted with $\mathrm{CH}_{2} \mathrm{Cl}_{2}(2 \times 10 \mathrm{~mL})$, washed with $\mathrm{H}_{2} \mathrm{O}(2 \times 10$ $\mathrm{mL})$, and the solvent was removed under reduced pressure to afford 9a as an orange oil (95 mg, 75\%). ${ }^{1} \mathrm{H}$ NMR (400 MHz, Methanol-d4) $\delta 7.78(\mathrm{~d}, J=1.9 \mathrm{~Hz}, 1 \mathrm{H}), 7.35(\mathrm{~d}, J=8.6 \mathrm{~Hz}, 1 \mathrm{H}), 7.30-7.22(\mathrm{~m}$, $2 \mathrm{H}), 3.72-3.67(\mathrm{~m}, 2 \mathrm{H}), 3.30(\mathrm{t}, J=6.8 \mathrm{~Hz}, 2 \mathrm{H}), 3.17(\mathrm{t}, J=7.0 \mathrm{~Hz}$, $2 \mathrm{H}), 1.78(\mathrm{p}, J=6.9 \mathrm{~Hz}, 2 \mathrm{H}) .{ }^{13} \mathrm{C}$ NMR (101 MHz, Methanol-d4) $\delta$ $173.8,173.7,135.4,128.9,125.2$, 123.9, 120. 7, 112.8, 111.8, 107.9, 47.5, 47.2, 47.0, 38.5, 36.2, 32.5, 32.4, 28.5. FTMS $m / z 352.0813$ [M $+\mathrm{H}]^{+}\left(\right.$calcd for $\left.\mathrm{C}_{14} \mathrm{H}_{19}{ }^{79} \mathrm{BrN}_{5} \mathrm{O}^{+}, 352.0767\right)$.

Amino-((4-(2-(6-bromo-1H-indol-3-yl)acetamido)butyl)amino)methaniminium 2,2,2-trifluoroacetate $(\mathbf{9 b})$. To a solution of $\mathbf{8 b}$ (0.19 g, $0.59 \mathrm{mmol}, 1.0$ equiv) and $N, N^{\prime}$-Di-Boc- $1 H$-pyrazole-1carboxamidine $(0.37 \mathrm{~g}, 1.17 \mathrm{mmol}, 2.0$ equiv $)$ in THF $(7 \mathrm{~mL})$ was added DIPEA $(0.21 \mathrm{~mL}, 1.17 \mathrm{mmol}, 2.0$ equiv). The mixture was stirred at $\mathrm{rt}$ for $3 \mathrm{~h}$, quenched with $\mathrm{H}_{2} \mathrm{O}(10 \mathrm{~mL})$, extracted with diethyl ether $(2 \times 10 \mathrm{~mL})$, washed with sat. $\mathrm{NaHCO}_{3}$ and brine $(10$ $\mathrm{mL}$ ), dried over $\mathrm{Na}_{2} \mathrm{SO}_{4}$, and concentrated. The crude product was purified on silica gel column chromatography [(EtOAc:Hept-n, 6:4)] to give the intermediate as a light white powder $(0.29 \mathrm{~g}, 86 \%) . \mathrm{R}_{\mathrm{f}}=$ 0.19 [(EtOAc: $n$-heptane, 4:1)]. IR $\left(\mathrm{cm}^{-1}\right) .3413,3286,2933,2866$, 2516, 2445, 2378, 2154, 1722, 1629, 1581, 1458, 1369, 1287, 1153, 1052, 1030, 877, 803, 739. ${ }^{1} \mathrm{H}$ NMR (400 MHz, Methanol-d 4 ) $\delta 7.71$ $(\mathrm{d}, J=1.8 \mathrm{~Hz}, 1 \mathrm{H}), 7.26(\mathrm{~d}, J=8.6 \mathrm{~Hz}, 1 \mathrm{H}), 7.21-7.16(\mathrm{~m}, 2 \mathrm{H})$, $3.60(\mathrm{~s}, 2 \mathrm{H}), 3.31-3.25(\mathrm{~m}, 2 \mathrm{H}), 3.21(\mathrm{t}, J=6.6,5.8 \mathrm{~Hz}, 2 \mathrm{H}), 1.52$ (s, 13H), 1.46 (s, 9H). ${ }^{13} \mathrm{C}$ NMR (101 MHz, Methanol- $\left.d_{4}\right) \delta 174.5$, $164.5,157.6,154.2,136.7,130.3,126.5,125.3,122.1,114,113.1$, $109.4,84.4,80.3,41.4,40.2,33.9,28.6,28.2,27.6,27.5$. FTMS $m / z$ $566.2031[\mathrm{M}+\mathrm{H}]^{+}\left(\right.$calcd for $\left.\mathrm{C}_{25} \mathrm{H}_{37}{ }^{79} \mathrm{BrN}_{5} \mathrm{O}_{5}{ }^{+}, 566.1973\right)$.

The intermediate $(0.24 \mathrm{~g}, 0.42 \mathrm{mmol}, 1.0$ equiv) was dissolved in $\mathrm{CH}_{2} \mathrm{Cl}_{2}(5 \mathrm{~mL})$ and a solution of TFA: $\mathrm{CH}_{2} \mathrm{Cl}_{2}(1: 1,10 \mathrm{~mL})$ was added. The reaction mixture was stirred at $\mathrm{rt}$ for $2 \mathrm{~h}$, quenched with $\mathrm{H}_{2} \mathrm{O}$, extracted with $\mathrm{CH}_{2} \mathrm{Cl}_{2}(2 \times 10 \mathrm{~mL})$, washed with $\mathrm{H}_{2} \mathrm{O}(2 \times 10$ $\mathrm{mL}$ ), and the solvent was removed under reduced pressure to afford $9 \mathrm{~b}$ as a green-orange oil $(167 \mathrm{mg}, 83 \%)$. IR $\left(\mathrm{cm}^{-1}\right) .3286,3181,2944$, 2125, 1633, 1566, 1436, 1436, 1182, 1134, 1026, 888, 840, 803, 724. ${ }^{1} \mathrm{H}$ NMR $\left(400 \mathrm{MHz}\right.$, Methanol- $\left.d_{4}\right) \delta 7.70(\mathrm{~d}, J=1.8 \mathrm{~Hz}, 1 \mathrm{H}), 7.27$ (d, $J=8.6 \mathrm{~Hz}, 1 \mathrm{H}), 7.20-7.16(\mathrm{~m}, 2 \mathrm{H}), 3.60(\mathrm{~s}, 2 \mathrm{H}), 3.19(\mathrm{t}, J=6.1$ $\mathrm{Hz}, 2 \mathrm{H}), 3.10(\mathrm{t}, J=6.9 \mathrm{~Hz}, 2 \mathrm{H}), 1.53-1.47(\mathrm{~m}, 4 \mathrm{H}) .{ }^{13} \mathrm{C} \mathrm{NMR}$ $\left(101 \mathrm{MHz}\right.$, Methanol- $\left.d_{4}\right) \delta 174.7,158.5,136.7,130.2,126.5,125.2$, 122 , 114.1, 113.1, 109.4, 42, 39.8, 33.8, 27.5, 27.0. FTMS $\mathrm{m} / z$ $366.0947[\mathrm{M}+\mathrm{H}]^{+}\left(\right.$calcd for $\left.\mathrm{C}_{15} \mathrm{H}_{21}{ }^{79} \mathrm{BrN}_{5} \mathrm{O}^{+}, 366.0924\right)$.

Amino-((5-(2-(6-bromo-1H-indol-3-yl)acetamido)pentyl)amino)methaniminium 2,2,2-trifluoroacetate (9c). To a solution of $8 \mathrm{c}$ $\left(0.40 \mathrm{~g}, 1.19 \mathrm{mmol}, 1.0\right.$ equiv) and $N, N^{\prime}$-Di-Boc-1H-pyrazole-1carboxamidine $(0.74 \mathrm{~g}, 2.39 \mathrm{mmol}, 2.0$ equiv) in THF $(8 \mathrm{~mL})$ was added DIPEA ( $0.42 \mathrm{~mL}, 2.39 \mathrm{mmol}, 2.0$ equiv). The mixture was stirred at rt for $3 \mathrm{~h}$, quenched with $\mathrm{H}_{2} \mathrm{O}(10 \mathrm{~mL})$, extracted with diethyl ether $(2 \times 10 \mathrm{~mL})$, washed with sat. $\mathrm{NaHCO}_{3}$ and brine $(10$ $\mathrm{mL}$ ), dried over $\mathrm{Na}_{2} \mathrm{SO}_{4}$, and concentrated. The crude product was purified on silica gel column chromatography [(EtOAc: $n$-heptane, $6: 4)]$ to give the intermediate as a light white powder $(0.576 \mathrm{~g}, 83 \%)$. $\mathrm{R}_{f}=0.26\left[\left(\right.\right.$ EtOAc: $n$-heptane, 4:1)]. IR $\left(\mathrm{cm}^{-1}\right) .3413,3288,2981$, 2936, 1722, 1618, 1577, 1417, 1369, 1328, 1134, 1058, 1030, 884, 799. ${ }^{1} \mathrm{H}$ NMR $\left(400 \mathrm{MHz}\right.$, Methanol- $\left.d_{4}\right) \delta 7.71(\mathrm{~d}, J=1.8 \mathrm{~Hz}, 1 \mathrm{H})$, $7.27(\mathrm{~d}, J=8.9 \mathrm{~Hz}, 1 \mathrm{H}), 7.21-7.17(\mathrm{~m}, 2 \mathrm{H}), 3.60(\mathrm{~s}, 2 \mathrm{H}), 3.27(\mathrm{t}, J=$ $7.2 \mathrm{~Hz}, 2 \mathrm{H}), 3.18(\mathrm{t}, J=6.8 \mathrm{~Hz}, 2 \mathrm{H}), 1.58-1.49(\mathrm{~m}, 13 \mathrm{H}), 1.46(\mathrm{~s}$, 9H), $1.33-1.26(\mathrm{~m}, 2 \mathrm{H}) .{ }^{13} \mathrm{C}$ NMR $\left(101 \mathrm{MHz}\right.$, Methanol- $\left.d_{4}\right) \delta$ $174.5,164.6,157.5,154.2,136.7,130.3,126.4,125.3,122.1,114$, $113.1,109.5,84.4,80.3,41.7,40.3,33.9,30,29.7,28.6,28.2,25.1$. FTMS $m / z 580.2158[\mathrm{M}+\mathrm{H}]^{+}$(calcd for $\mathrm{C}_{26} \mathrm{H}_{39}{ }^{79} \mathrm{BrN}_{5} \mathrm{O}_{5}{ }^{+}$, 580.2129).

The intermediate $(0.55 \mathrm{~g}, 0.95 \mathrm{mmol}, 1.0$ equiv) was dissolved in $\mathrm{CH}_{2} \mathrm{Cl}_{2}(5 \mathrm{~mL})$ and a solution of TFA: $\mathrm{CH}_{2} \mathrm{Cl}_{2}(1: 1,10 \mathrm{~mL})$ was added. The reaction mixture was stirred at $\mathrm{rt}$ for $2 \mathrm{~h}$, quenched with $\mathrm{H}_{2} \mathrm{O}$, extracted with $\mathrm{CH}_{2} \mathrm{Cl}_{2}(2 \times 10 \mathrm{~mL})$, washed with $\mathrm{H}_{2} \mathrm{O}(2 \times 10$ $\mathrm{mL}$ ) and the solvent was removed under reduced pressure to afford $9 \mathrm{c}$ as a yellow-orange oil (112 mg, 24\%). IR $\left(\mathrm{cm}^{-1}\right) .3283,3176$, 2940, 2125, 1633, 1566, 1462, 1436, 1182, 1138, 1028, 888, 840, 803, 724. ${ }^{1} \mathrm{H}$ NMR $\left(400 \mathrm{MHz}\right.$, Methanol- $\left.d_{4}\right) \delta 7.70(\mathrm{~d}, J=1.9 \mathrm{~Hz}, 1 \mathrm{H})$, $7.27(\mathrm{~d}, J=8.6 \mathrm{~Hz}, 1 \mathrm{H}), 7.20-7.16(\mathrm{~m}, 2 \mathrm{H}), 3.60(\mathrm{~s}, 2 \mathrm{H}), 3.17(\mathrm{t}, J=$ $6.9 \mathrm{~Hz}, 2 \mathrm{H}), 3.04(\mathrm{t}, J=7.1 \mathrm{~Hz}, 2 \mathrm{H}), 1.54-1.44(\mathrm{~m}, 4 \mathrm{H}), 1.32-1.25$ $(\mathrm{m}, 2 \mathrm{H}) .{ }^{13} \mathrm{C}$ NMR $\left(101 \mathrm{MHz}\right.$, Methanol- $\left.d_{4}\right) \delta 174.6,158.5,136.7$, 130.2, 126.5, 125.2, 122.1, 114.1, 113.1, 109.4, 42.3, 40.2, 33.9, 29.9, 29.3, 24.8. FTMS $\mathrm{m} / \mathrm{z} 380.1092[\mathrm{M}+\mathrm{H}]^{+}$(calcd for $\left.\mathrm{C}_{16} \mathrm{H}_{23}{ }^{79} \mathrm{BrN}_{5} \mathrm{O}^{+}, 380.1080\right)$.

2-(6-Bromo-1H-indol-3-yl)- $\mathrm{N}$-(6-guanidinohexyl)- $\mathrm{N}$-methylacetamide Trifluoroacetate (9d). To a solution of crude $8 \mathbf{e}(0.049 \mathrm{~g}$, $0.14 \mathrm{mmol}, 1.0$ equiv) and $N, N^{\prime}$-Di-Boc- $1 H$-pyrazole-1-carboxamidine $(0.087 \mathrm{~g}, 0.28 \mathrm{mmol}, 2.0$ equiv $)$ in THF $(10 \mathrm{~mL})$ was added DIPEA ( $0.05 \mathrm{~mL}, 0.28 \mathrm{mmol}, 2.0$ equiv). The mixture was stirred at $\mathrm{rt}$ for $3 \mathrm{~h}$, quenched with $\mathrm{H}_{2} \mathrm{O}(20 \mathrm{~mL})$, extracted with diethyl ether (3 $\times 20 \mathrm{~mL}$ ), washed with sat. $\mathrm{NaHCO}_{3}$ and brine, dried over $\mathrm{Na}_{2} \mathrm{SO}_{4}$, and concentrated. The diboc-intermediate compound (confirmed by HRMS) was used without further purification and dissolved in TFA: $\mathrm{CH}_{2} \mathrm{Cl}_{2}(1: 1,10 \mathrm{~mL})$, and the reaction mixture was stirred at room temperature for $2 \mathrm{~h}$, quenched with $\mathrm{H}_{2} \mathrm{O}$, extracted with $\mathrm{CH}_{2} \mathrm{Cl}_{2}(2 \times 10 \mathrm{~mL})$, washed with $\mathrm{H}_{2} \mathrm{O}(2 \times 10 \mathrm{~mL})$, and the solvent was removed under reduced pressure to afford $9 \mathrm{~d}$ as brown oil (19 $\mathrm{mg}, 26 \%) .{ }^{1} \mathrm{H}$ NMR (400 MHz, Methanol- $\left.d_{4}\right) \delta 7.63(\mathrm{dd}, J=4.9,1.9$ $\mathrm{Hz}, 1 \mathrm{H}), 7.18(\mathrm{dd}, J=8.6,3.1 \mathrm{~Hz}, 1 \mathrm{H}), 7.13-7.01(\mathrm{~m}, 2 \mathrm{H}), 3.72(\mathrm{~d}, J$ $=0.9 \mathrm{~Hz}, 2 \mathrm{H}), 3.30(\mathrm{td}, J=7.4,2.5 \mathrm{~Hz}, 2 \mathrm{H}), 3.02-2.96(\mathrm{~m}, 2 \mathrm{H})$, $2.97(\mathrm{~d}, J=11.6 \mathrm{~Hz}, 3 \mathrm{H}), 1.49-1.28(\mathrm{~m}, 4 \mathrm{H}), 1.23-1.02(\mathrm{~m}, 4 \mathrm{H})$. ${ }^{13} \mathrm{C}$ NMR (101 MHz, Methanol- $\left.d_{4}\right) \delta: 172.5,157.2,135.4,128.9$, $124.7,123.9,121.0,112.6,111.7,107.5,54.4,40.9,34.9,32.5,31.1$, 
28.3, 26.4, 25.7. FTMS $m / z$ 408.1406 $[\mathrm{M}+\mathrm{H}]^{+}$(calcd for $\left.\mathrm{C}_{18} \mathrm{H}_{27}{ }^{79} \mathrm{BrN}_{5} \mathrm{O}^{+}, 408.1393\right)$.

3-(2-(6-Bromo- $1 \mathrm{H}$-indol-3-yl)acetamido)- $\mathrm{N}, \mathrm{N}, \mathrm{N}$-trimethylpropan-1-aminium lodide (10). To a $0{ }^{\circ} \mathrm{C}$ solution of 8 a (100 mg, 0.32 mmol, 1.0 equiv) and glacial acetic acid $(72 \mu \mathrm{L}, 1.28 \mathrm{mmol}, 4.0$ equiv) in $\mathrm{MeOH}(5 \mathrm{~mL})$ under argon atmosphere, was added sodium cyanoborohydride $(40 \mathrm{mg}, 0.64 \mathrm{mmol}, 2.0$ equiv). A solution of formaldehyde ( $21 \mu \mathrm{L}, 0.38 \mathrm{mmol}, 2.4$ equiv) in $\mathrm{MeOH}(2 \mathrm{~mL})$ was carefully added dropwise over $10 \mathrm{~min}$, and then stirred at $\mathrm{rt}$ for $21 \mathrm{~h}$, quenched with $\mathrm{Na}_{2} \mathrm{CO}_{3}(2 \mathrm{M})$ until $\mathrm{pH} 8-9$ and concentrated under reduced pressure. The residue was taken up in $\mathrm{CHCl}_{3}$, washed with brine and dried over $\mathrm{Na}_{2} \mathrm{SO}_{4}$, filtered, and concentrated to obtain the dimethylated product. To a $0{ }^{\circ} \mathrm{C}$ solution of the dimethylated product $(80 \mathrm{mg}, 0.24 \mathrm{mmol})$ in $\mathrm{CHCl}_{3}(1 \mathrm{~mL})$ was added iodomethane $(0.05$ $\mathrm{mL}, 0.72 \mathrm{mmol}, 10$ equiv) in portions $(\times 3)$. The precipitate was isolated, coevaporated with $\mathrm{MeOH}(\times 3)$ to afford the product 10 as a light yellow oil $(81 \mathrm{mg}, 53 \%) .{ }^{1} \mathrm{H}$ NMR $\left(400 \mathrm{MHz}\right.$, Methanol- $\left.d_{4}\right) \delta$ $7.80(\mathrm{~d}, J=1.9 \mathrm{~Hz}, 1 \mathrm{H}), 7.39-7.28(\mathrm{~m}, 2 \mathrm{H}), 7.23(\mathrm{dd}, J=8.7,1.9$ $\mathrm{Hz}, 1 \mathrm{H}), 3.68(\mathrm{~s}, 2 \mathrm{H}), 3.29(\mathrm{t}, J=6.4 \mathrm{~Hz}, 2 \mathrm{H}), 3.25-3.18(\mathrm{~m}, 2 \mathrm{H})$, $3.00(\mathrm{~s}, 9 \mathrm{H}), 2.01-1.86(\mathrm{~m}, 2 \mathrm{H}) .{ }^{13} \mathrm{C}$ NMR $\left(101 \mathrm{MHz}\right.$, Methanol- $\left.d_{4}\right)$ $\delta 173.6,135.4,128.9,125.6,124.0,120.8,113.0,111.8,108.1,64.3$, 52.3 , 47.7, 47. 5, 47.2, 47.0, 35.7, 32.0. FTMS $m / z$ 352.1027 [M] ${ }^{+}$ (calcd for $\mathrm{C}_{16} \mathrm{H}_{23}{ }^{79} \mathrm{BrN}_{5} \mathrm{O}^{+}, 352.1019$ ).

Barnacle Settlement. The barnacle cyprids were reared in a laboratory rearing system, and their settlement was evaluated according to the methods of Berntsson at Tjärnö Marine Biological Laboratory. ${ }^{54}$ In brief, a total of $18-22$ freshly molted A. improvisus cyprids were added to nontreated polystyrene Petri dishes $(48 \mathrm{~mm}$, Nunc \#150340) containing $10 \mathrm{~mL}$ of filtered $(0.2 \mu \mathrm{m})$ seawater (freshly collected from a depth of $45 \mathrm{~m}$ from the Kosterfjord (Sweden), filtered through $20 \mu \mathrm{m}$ filter and diluted with fresh water to 25 psu prior to use), and the compounds were serially diluted with DMSO (10 $\mu \mathrm{L}$ added) to yield the desired concentration series. The dishes were incubated at ambient temperature $\left(20-25^{\circ} \mathrm{C}\right)$ for 5 days, and at the end of the experiment, the number of metamorphosed juvenile barnacles, as well as live and dead cyprids, was assessed under a dissection microscope. The concentration of a compound leading to $50 \%$ inhibition of the settlement (metamorphosed cyprids) compared to the control was reported as the $\mathrm{IC}_{50}$ value. Dead cyprids are not included in the $\mathrm{IC}_{50}$ value. Dishes with $10 \mu \mathrm{L}$ of DMSO added served as negative control. Sea-nine was used as positive control, and each test concentration was replicated four times $(n=4)$.

Coating Development. A biodegradable poly $(\varepsilon$-caprolactone-co$\delta$-valerolactone) (80:20) polymer was prepared according to previously published methodology ${ }^{48}$ and solubilized in xylene (mixture of isomers) $(1: 1 \mathrm{w} / \mathrm{w})$. The compound was dissolved in $\mathrm{MeOH}$ ( $1 \mathrm{M}$ final concentration) and added to polymer solution to yield a final compound concentration of $0.1 \mathrm{mg} / \mathrm{L}$. The solution was vortexed for $1 \mathrm{~min}$ and subsequently ultrasonicated $(3 \times 15 \mathrm{~min})$ to yield a homogeneous coating solution which was applied at a thickness of $200 \mu \mathrm{m}$ to PVC panels $\left(10 \times 10 \mathrm{~cm}^{2}\right)$ using a film applicator. The coating was allowed to dry for $24 \mathrm{~h}$ at ambient temperature before further analyses and studies.

Field Studies. The coated and uncoated reference PVC panels as well as control panels coated with polymer in the absence of compound were mounted on structures and immersed at a depth of 1 $\mathrm{m}$ deep in the port of Kernével in Lorient (France, $47^{\circ} 42^{\prime} 20.78^{\prime \prime} \mathrm{N}$, $3^{\circ} 23^{\prime} 40.68^{\prime \prime} \mathrm{E}$ ). Each type of panel was included in triplicate in the field study. The immersion was carried out in spring at an average water temperature of $16{ }^{\circ} \mathrm{C}$ and a salinity of $29 \mathrm{mg} / \mathrm{mL}$. The panels were regularly controlled and photographed to document and assess the settlement of organisms. After day 84, the panels were retrieved, and the extent and type of colonization was analyzed and quantified.

Prior to quantification of growth, the panels were gently rinsed to remove loosely adhered material and the adhesion of cells was observed with confocal laser scanning microscopy (Zeiss, LSM 710) by using a $40 \times$ oil immersion objective for bacteria and $20 \times$ air objective for diatoms. Adhered bacteria were observed with Syto 9 nucleic acid stain $\left(5 \mu \mathrm{M}, \lambda_{\text {excitation }}=488 \mathrm{~nm}, \lambda_{\text {emission }}=498-540 \mathrm{~nm}\right)$. Adhered diatoms were observed by their fluorescence $\left(\lambda_{\text {excitation }}=633\right.$ $\left.\mathrm{nm}, \lambda_{\text {emission }}=638-720 \mathrm{~nm}\right)$. The extent of growth, biovolume, and overlap percentage was determined with a JAVA program (Universite' de Bretagne-sud, Lorient, France). ${ }^{50,51}$

\section{ASSOCIATED CONTENT}

\section{Supporting Information}

The Supporting Information is available free of charge at https://pubs.acs.org/doi/10.1021/acs.jnatprod.0c00881.

${ }^{1} \mathrm{H}$ NMR and ${ }^{13} \mathrm{C}$ NMR data for all new synthetic compounds and synthesized phidianidine A together with $2 \mathrm{D}$ NMR data for 8a, 9c, and 10 (PDF)

\section{AUTHOR INFORMATION}

\section{Corresponding Author}

Johan Svenson - Department of Chemistry, Chemical Synthesis and Analysis Group, UiT The Arctic University of Norway, N-9037 Tromsø, Norway; Department of Chemistry, Biomaterial \& Textile, RISE Research Institutes of Sweden, 50115 Borås, Sweden; 다이.org/0000-00024729-9359; Phone: +64 27272 1876;

Email: Johan.svenson@cawthron.org.nz

\section{Authors}

Christophe Labriere - Department of Chemistry, Chemical Synthesis and Analysis Group, UiT The Arctic University of Norway, N-9037 Tromsø, Norway

Vijayaragavan Elumalai - Department of Chemistry, Chemical Synthesis and Analysis Group, UiT The Arctic University of Norway, N-9037 Tromsø, Norway

Jannie Staffansson - Department of Chemistry, Chemical Synthesis and Analysis Group, UiT The Arctic University of Norway, N-9037 Tromsø, Norway

Gunnar Cervin - Department of Marine Sciences, Tjärnö Marine Laboratory, University of Gothenburg, SE-452 96 Strömstad, Sweden

Tiffany Le Norcy - Univ. Bretagne-Sud, EA 3884, LBCM, IUEM, F-56100 Lorient, France

Hugo Denardou - Department of Chemistry, Chemical Synthesis and Analysis Group, UiT The Arctic University of Norway, N-9037 Tromsø, Norway

Karine Réhel - Univ. Bretagne-Sud, EA 3884, LBCM, IUEM, F-56100 Lorient, France

Lindon W. K. Moodie - Department of Medicinal Chemistry and Uppsala Antibiotic Centre, Biomedical Centre, Uppsala University, 75123 Uppsala, Sweden; (1) orcid.org/00000002-9500-4535

Claire Hellio - Univ. Brest, Laboratoire des Sciences de l'Environnement MARin (LEMAR), CNRS, IRD, IFREMER, Brest 29285, France

Henrik Pavia - Department of Marine Sciences, Tjärnö Marine Laboratory, University of Gothenburg, SE-452 96 Strömstad, Sweden

Jørn H. Hansen - Department of Chemistry, Chemical Synthesis and Analysis Group, UiT The Arctic University of Norway, N-9037 Tromsø, Norway; 이이.org/00000002-3888-5217

Complete contact information is available at: https://pubs.acs.org/10.1021/acs.jnatprod.0c00881 


\section{Author Contributions}

The manuscript was written through contributions of all authors. All authors have given approval to the final version of the manuscript.

\section{Notes}

The authors declare no competing financial interest.

\section{ACKNOWLEDGMENTS}

For C.L., J.H.H., J.S., and V.E., this work was partly supported with grants from the Norwegian Research Council (ES508288 and 275043 CasCat). L.W.K.M. acknowledges the Uppsala Antibiotic Centre for support. H.P. and G.C. were supported by the Centre for Marine Chemical Ecology (http://www. cemace.science.gu.se) at the University of Gothenburg. Finally, the authors are grateful to V. Bhave (TOC) for providing the image of Phidiana militaris.

\section{REFERENCES}

(1) Svenson, J. Phytochem. Rev. 2013, 12, 567-578.

(2) Gerwick, W. H.; Moore, B. S. Chem. Biol. 2012, 19, 85-98.

(3) Molinski, T. F.; Dalisay, D. S.; Lievens, S. L.; Saludes, J. P. Nat. Rev. Drug Discovery 2009, 8, 69-85.

(4) Zhang, G.; Li, J.; Zhu, T.; Gu, Q.; Li, D. Curr. Opin. Biotechnol. 2016, 42, 13-23.

(5) Trepos, R.; Cervin, G.; Hellio, C.; Pavia, H.; Stensen, W.; Stensvåg, K.; Svendsen, J.-S.; Haug, T.; Svenson, J. J. Nat. Prod. 2014, 77, 2105-2113.

(6) Fusetani, N. Nat. Prod. Rep. 2011, 28, 400-410.

(7) Qian, P. Y.; Li, Z.; Xu, Y.; Li, Y.; Fusetani, N. Biofouling 2015, 31, 101-122.

(8) Yebra, D. M.; Kiil, S.; Dam-Johansen, K. Prog. Org. Coat. 2004, 50, 75-104.

(9) Chambers, L. D.; Stokes, K. R.; Walsh, F. C.; Wood, R. J. Surf.

Coat. Technol. 2006, 201, 3642-3652.

(10) Vinagre, P. A.; Simas, T.; Cruz, E.; Pinori, E.; Svenson, J. JMSE 2020, 8, 495 .

(11) Schultz, M. P. Biofouling 2007, 23, 331-341.

(12) Videla, H. A.; Characklis, W. G. Int. Biodeterior. Biodegrad. 1992, 29, 195-212.

(13) Trepos, R.; Pinori, E.; Jonsson, P.; Berglin, M.; Svenson, J.; Coutinho, R.; Lausmaa, J.; Hellio, C. J. Ocean Technol. 2014, 9, 7-18.

(14) Litaudon, M.; Guyot, M. Tetrahedron Lett. 1986, 27 (37), $4455-4456$.

(15) Hanssen, K. Ø.; Cervin, G.; Trepos, R.; Petitbois, J.; Haug, T.; Hansen, E.; Andersen, J. H.; Pavia, H.; Hellio, C.; Svenson, J. Mar. Biotechnol. 2014, 16 (6), 684-694.

(16) Sjögren, M.; Göransson, U.; Johnson, A. L.; Dahlström, M.; Andersson, R.; Bergman, J.; Jonsson, P. R.; Bohlin, L. J. Nat. Prod. 2004, 67, 368-372.

(17) Sjögren, M.; Johnson, A. L.; Hedner, E.; Dahlström, M.; Göransson, U.; Shirani, H.; Bergman, J.; Jonsson, P. R.; Bohlin, L. Peptides 2006, 27, 2058-2064.

(18) Labriere, C.; Andersen, J. H.; Albrigtsen, M.; Hansen, J. H.; Svenson, J. Bioorg. Chem. 2019, 84, 106-114.

(19) Olsen, E. K.; Hansen, E.; Moodie, L. W.; Isaksson, J.; Sepčić, K.; Cergolj, M.; Svenson, J.; Andersen, J. H. Org. Biomol. Chem. 2016, 14, 1629-1640.

(20) Melander, C.; Moeller, P. D.; Ballard, T. E.; Richards, J. J.; Huigens, R. W., III; Cavanagh, J. Int. Biodeterior. Biodegrad. 2009, 63, 529-532.

(21) Richards, J. J.; Ballard, T. E.; Huigens, R. W., III; Melander, C. ChemBioChem 2008, 9, 1267-1279.

(22) Tsukamoto, S.; Kato, H.; Hirota, H.; Fusetani, N. J. Nat. Prod. 1996, 59, 501-503.

(23) Tadesse, M.; Strøm, M. B.; Svenson, J.; Jaspars, M.; Milne, B. F.; Tørfoss, V.; Andersen, J. H.; Hansen, E.; Stensvåg, K.; Haug, T. Org. Lett. 2010, 12, 4752-4755.
(24) Hopmann, K. H.; Šebestík, J.; Novotna, J.; Stensen, W.; Urbanova, M.; Svenson, J.; Svendsen, J. S.; Bouř, P.; Ruud, K. J. Org. Chem. 2012, 77, 858-869.

(25) Tadesse, M.; Svenson, J.; Jaspars, M.; Strøm, M. B.; Abdelrahman, M. H.; Andersen, J. H.; Hansen, E.; Kristiansen, P. E.; Stensvåg, K.; Haug, T. Tetrahedron Lett. 2011, 52, 1804-1806.

(26) Ortlepp, S.; Sjögren, M.; Dahlström, M.; Weber, H.; Ebel, R.; Edrada, R.; Thoms, C.; Schupp, P.; Bohlin, L.; Proksch, P. Mar. Biotechnol. 2007, 9, 776-785.

(27) Bayer, M.; Hellio, C.; Maréchal, J. P.; Frank, W.; Lin, W.; Weber, H.; Proksch, P. Mar. Biotechnol. 2011, 13, 1148-1158.

(28) Lind, K. F.; Hansen, E.; Østerud, B.; Eilertsen, K. E.; Bayer, A.; Engqvist, M.; Leszczak, K.; Jørgensen, T. Ø.; Andersen, J. H. Mar. Drugs 2013, 11, 2655-2666.

(29) Tadesse, M.; Svenson, J.; Sepčić, K.; Trembleau, L.; Engqvist, M.; Andersen, J. H.; Jaspars, M.; Stensvåg, K.; Haug, T. J. Nat. Prod. 2014, 77, 364-369.

(30) Moodie, L. W.; Sepčić, K.; Turk, T.; Frangež, R.; Svenson, J. Nat. Prod. Rep. 2019, 36, 1053-1092.

(31) Carbone, M.; Li, Y.; Irace, C.; Mollo, E.; Castelluccio, F.; Di Pascale, A.; Cimino, G.; Santamaria, R.; Guo, Y.-W.; Gavagnin, M. Org. Lett. 2011, 13, 2516-2519.

(32) Liu, J.; Li, H.; Chen, K. X.; Zuo, J.-P.; Guo, Y. W.; Tang, W.; Li, X. W. J. Med. Chem. 2018, 61, 11298-11308.

(33) Brogan, J. T.; Stoops, S. L.; Lindsley, C. W. ACS Chem. Neurosci. 2012, 3, 658-64.

(34) Vitale, R. M.; Gatti, M.; Carbone, M.; Barbieri, F.; Felicità, V.; Gavagnin, M.; Florio, T.; Amodeo, P. ACS Chem. Biol. 2013, 8, 27622770.

(35) Moodie, L. W.; Cervin, G.; Trepos, R.; Labriere, C.; Hellio, C.; Pavia, H.; Svenson, J. Mar. Biotechnol. 2018, 20, 257-267.

(36) Moodie, L. W.; Trepos, R.; Cervin, G.; Larsen, L.; Larsen, D. S.; Pavia, H.; Hellio, C.; Cahill, P.; Svenson, J. J. Nat. Prod. 2017, 80, $515-525$.

(37) Brooke, D. G.; Cervin, G.; Champeau, O.; Harwood, D. T.; Pavia, H.; Selwood, A. I.; Svenson, J.; Tremblay, L. A.; Cahill, P. L. Biofouling 2018, 34, 950-961.

(38) Lin, H. Y.; Snider, B. B. J. Org. Chem. 2012, 77, 4832-6.

(39) Thomason, J. C.; Hills, J. M.; Clare, A. S.; Neville, A.; Richardson, M. Hydrobiologia 1998, 375, 191-201.

(40) Schultz, M. P.; Bendick, J. A.; Holm, E. R.; Hertel, W. M. Biofouling 2011, 27, 87-98.

(41) Jonsson, P. R.; Wrange, A.-L.; Lind, U.; Abramova, A.; Ogemark, M.; Blomberg, A. J. Visualized Exp. 2018, e57825.

(42) Svenson, J.; Karstad, R.; Flaten, G. E.; Brandsdal, B. O.; Brandl, M.; Svendsen, J. S. Mol. Pharmaceutics 2009, 6, 996-1005.

(43) Moodie, L. W.; Žužek, M. C.; Frangež, R.; Andersen, J. H.; Hansen, E.; Olsen, E. K.; Cergolj, M.; Sepčić, K.; Hansen, K.; Svenson, J. Org. Biomol. Chem. 2016, 14, 11220-11229.

(44) Moodie, L. W. K.; Trepos, R.; Cervin, G.; Bråthen, K. A.; Lindgård, B.; Reiersen, R.; Cahill, P.; Pavia, H.; Hellio, C.; Svenson, J. J. Nat. Prod. 2017, 80, 2001-2011.

(45) Albada, B.; Metzler-Nolte, N. Acc. Chem. Res. 2017, 50, 25102518.

(46) Ciriminna, R.; Bright, F. V.; Pagliaro, M. ACS Sustainable Chem. Eng. 2015, 3, 559-565.

(47) Kyei, S. K.; Darko, G.; Akaranta, O. Journal of Coatings Technology Research 2020, 17, 315.

(48) Faÿ, F.; Renard, E.; Langlois, V.; Linossier, I.; Vallée-Rehel, K. Eur. Polym. J. 2007, 43, 4800-4813.

(49) Sánchez-Lozano, I.; Hernández-Guerrero, C. J.; Muñoz-Ochoa, M.; Hellio, C. Int. J. Mol. Sci. 2019, 20, 4863.

(50) Le Norcy, T.; Faÿ, F.; Obando, C. Z.; Hellio, C.; Réhel, K.; Linossier, I. Int. Biodeterior. Biodegrad. 2019, 139, 54-61.

(51) Norcy, T. L.; Niemann, H.; Proksch, P.; Linossier, I.; ValléeRéhel, K.; Hellio, C.; Faÿ, F. Int. J. Mol. Sci. 2017, 18, 1520.

(52) Manzo, E.; Pagano, D.; Carbone, M.; Ciavatta, M. L.; Gavagnin, M. ARKIVOC 2012, 2012, 220-228. 
(53) Chadwick, J.; Jones, M.; Mercer, A. E.; Stocks, P. A.; Ward, S. A.; Park, B. K.; O’Neill, P. M. Bioorg. Med. Chem. 2010, 18, 25862597.

(54) Berntsson, K. M.; Jonsson, P. R.; Lejhall, M.; Gatenholm, P. J. Exp. Mar. Biol. Ecol. 2000, 251, 59-83. 